\title{
Kinetics of Biotic and Abiotic CO Production during the Initial Phase of Biowaste Composting
}

\author{
Sylwia Stegenta-Dąbrowska ${ }^{1}$, Karolina Sobieraj $^{1}{ }^{\circledR}$, Jacek A. Koziel ${ }^{2}{ }^{\circledR}$, Jerzy Bieniek ${ }^{1}$ \\ and Andrzej Białowiec 1,2,*(D) \\ 1 Faculty of Life Sciences and Technology, Wrocław University of Environmental and Life Sciences, \\ 37a Chełmońskiego Str., 51-630 Wrocław, Poland; sylwia.stegenta@upwr.edu.pl (S.S.-D.); \\ karolina.sobieraj@upwr.edu.pl (K.S.); jerzy.bieniek@upwr.edu.pl (J.B.) \\ 2 Department of Agricultural and Biosystems Engineering, Iowa State University, 605 Bissell Road, \\ Ames, IA 50011, USA; koziel@iastate.edu \\ * Correspondence: andrzej.bialowiec@upwr.edu.pl or andrzejb@iastate.edu; Tel.: +48-71-320-59731
}

Received: 31 August 2020; Accepted: 13 October 2020; Published: 19 October 2020

\begin{abstract}
Knowledge of kinetic parameters of $\mathrm{CO}$ production during biowaste composting is significantly important for the prediction of its course and estimation of total gas quantity. This allows increasing the control of the process, to minimize its negative impact on the environment and to protect the occupational safety of employees exposed to $\mathrm{CO}$ in the biowaste composting plant. For the first time, a full study of the influence of temperature and biowaste sterilization on the kinetics of $\mathrm{CO}$ production is presented. The lab-scale experiments used a mixture of green waste, dairy cattle manure, and sawdust in two variants: sterilized and non-sterilized samples. The process was carried out in controlled temperature reactors with measuring the concentrations of $\mathrm{CO}, \mathrm{O}_{2}$, and $\mathrm{CO}_{2}$ every $12 \mathrm{~h} . \mathrm{CO}$ production and $k$ value increased with temperature. However, higher $\mathrm{CO}$ production was observed in biotic conditions between $10 \sim 50{ }^{\circ} \mathrm{C}$, suggesting the biotic $\mathrm{CO}$ formation and 1st-order kinetics. The abiotic (thermochemical) process was more efficiently generating $\mathrm{CO}$ above $50{ }^{\circ} \mathrm{C}$, described with a 0 -order kinetic model. Additionally, the rate constant $(k)$ value of $\mathrm{CO}$ production under biotic conditions was increasing up to a temperature of $60^{\circ} \mathrm{C}$, above which a slight decrease in $\mathrm{CO}$ production rate was observed at $70^{\circ} \mathrm{C}$. The presented results are the basis for further studies focused on the feasibility of (1) the mitigation and (2) valorization of CO production during the biowaste biostabilization are warranted.
\end{abstract}

Keywords: waste management; aerobic digestion; biowaste; carbon monoxide; green chemistry; biorenewables; kinetic modeling; GHGs mitigation; biotic; abiotic

\section{Introduction}

Carbon monoxide (CO) is an odorless gas, without color or taste, with a strong toxic effect on living organisms. It is also toxic to many microorganisms due to its ability to inhibit electron transport [1].

Composting and aerobic biostabilization processes of biowaste are sources of CO production, besides major ones such as natural forest fires and incomplete fuel combustion and also through biochar production [2]. Production of $\mathrm{CO}$ is a result of the biological decomposition of organic matter, which also generates $\mathrm{CO}_{2}, \mathrm{CH}_{4}, \mathrm{H}_{2}$, nitrogen compounds, $\mathrm{VOC}$, and $\mathrm{H}_{2} \mathrm{~S}$ [3]. $\mathrm{CO}$ emissions have been observed during the composting of green waste [4], green waste with manure [5], organic waste [2], and aerobic biostabilization of the municipal waste [6]. The detection of $\mathrm{CO}$ during the pioneering experiments was a surprise due to the widespread belief in its primary production by incomplete combustion [7].

In recent years, the interest in gas emissions during composting in a laboratory, semi-technical, and full-scale conditions has increased [8-11] and could be a part of the worldwide circular economy [12]. 
Initial work focused on gas sampling [13], gas concentrations in the compost pores or above the pile surface $\left(\mathrm{CO}_{2}, \mathrm{NH}_{3}, \mathrm{~N}_{2} \mathrm{O}, \mathrm{CH}_{4}\right.$, and $\left.\mathrm{CO}\right)$ [8], spatial and temporal variability of compost gases [14], the influence of the feedstock (source-separated organic household waste and food waste; [3]) (agricultural waste [15]), municipal waste [16], including the separated organic fraction [17], green waste [18], particle size on the gaseous products emission [19].

There is still a lack of systematic knowledge in the literature analyzing the kinetics of $\mathrm{CO}$ production during aerobic biostabilization of biowaste. To date, soil science provides the most important literature in the field of $\mathrm{CO}$ formation kinetics related to the decomposition of organic matter. Conrad and Seiler [20], studied the simultaneous production and utilization of CO in three types of soils and developed early models. CO consumption follows the 1st-order reaction kinetics:

$$
\frac{d m}{d t}=k_{c o} m
$$

where:

$k_{c o}-\mathrm{CO}$ consumption constant rate $\left(\mathrm{s}^{-1}\right)$,

$m$-the mass of $\mathrm{CO}(\mathrm{mg})$,

$t$-time (s),

while the $\mathrm{CO}$ production follows apparent zero-order reaction kinetics:

$$
\frac{d m}{d t}=k_{p}
$$

where:

$k_{p}$ - CO production rate $\left(\mathrm{mg} \cdot \mathrm{s}^{-1}\right)$.

Since CO utilization and production occurs simultaneously, the mass balance is as follows:

$$
\frac{d m}{d t}=k_{p}-k_{c o} m
$$

Integration with the boundary conditions of $t=0, m=m_{0}$, and $t=\infty, m=m_{e}$, results in the CO utilization rate constant [18]:

$$
k_{c o}=\frac{1}{t} \ln \frac{m_{0}-m_{e}}{m-m_{e}}
$$

where:

$m_{0}, m_{e}$ - equilibrium values $(\mathrm{mg})$.

$\mathrm{CO}$ production from biological processes occurs under both aerobic and anaerobic conditions, with the latter being greater and correlated with $\mathrm{O}_{2}$ availability [3]. Researchers recognize the dual (biotic/abiotic) nature of $\mathrm{CO}$ production, but the question of the driving mechanisms remains open. Some argue that $\mathrm{CO}$ production is based on thermochemical processes and does not depend on the activity of microorganisms found in composted material [19]. These authors have shown that CO emissions are highly dependent on the temperature and amount of $\mathrm{O}_{2}[5]$. The temperature dependence and diurnal changes to $\mathrm{CO}$ emissions from soil were reported [21]. Other abiotic factors, such as UV radiation, type of material, humidity, and organic matter content, have an impact on CO generation from soil [22,23].

An interesting discovery was made by Rich and King [24], who found that $\mathrm{CO}$ is not only produced but also utilized by methanogenic, acetogenic, and sulfate-reducing bacteria in compost [25]. The biotic origin of $\mathrm{CO}$ is not fully understood; one hypothesis being that it is formed from abiotic substrates, including porphyrins, polyphenols, and aromatic acids [26]. 
Despite the agreement that $\mathrm{CO}$ production can occur via biotic and abiotic processes-its origins and mechanisms have not been explained exhaustively. It is also necessary to know the full impact of temperature as one of the key parameters of the waste composting process on CO production. Knowledge about the kinetic parameters of $\mathrm{CO}$ production during composting is significantly important for the estimation of its production rate and total quantity. This allows increasing the control of the process, minimizing its negative impact on the environment, increasing the sustainability, and, what is immediately more important, to protect the safety of employees exposed to $\mathrm{CO}$ in the biowaste composting plant. In the literature, there are many works dealing with the subject of workers' exposure related to the composting process exposure to volatile organic compounds (VOC), bacteria, fungi, organic dust, odors, leachates, molds, and other substances [27-31]. On the other hand, there are no sources providing information on the risk of $\mathrm{CO}$ poisoning; quantitative comparisons with the risk of other pollutants mentioned above do not exist either. However, this topic should not be ignored due to the toxicity of $\mathrm{CO}$ for humans and the nature of the work undertaken in composting plants. Most of the people employed perform manual labor, whose frequency and depth of breathing is increased due to their duties, which in turn increases their potential exposure to CO. Longterm exposure to CO may cause a number of diseases related to, among others, the respiratory and circulatory systems [32]. In the long-term, these results could also help save money in composting treatment plants. Designing the process to avoid $\mathrm{CO}$ emissions will reduce expenses related to the abstention \& turnovers of employees at work or pay compensation for health impairment [33].

In recent work [4], we have indicated that $\mathrm{CO}$ production during biowaste aerobic digestion can be biotic and abiotic in nature. The main observation was that $\mathrm{CO}$ concentrations varied throughout the process, with the temperature being the main influencing factor. The temperature's effect was more significant in the case of non-sterilized samples. This observation highlights the fact that microorganisms are involved in net $\mathrm{CO}$ production. These results add to the small, yet growing evidence that biotic processes generate $\mathrm{CO}$. What are the details of the kinetics of $\mathrm{CO}$ formation according to aerobic biowaste stabilization process parameters? Trying to answer this question requires reexamining the same dataset, i.e., $\mathrm{CO}, \mathrm{O}_{2}$, and $\mathrm{CO}_{2}$ concentrations reported in [4], with extensive statistical analysis to reveal the kinetics of $\mathrm{CO}$ formation.

Therefore, this novel and significant research aim to explain the effect of compost process temperature and microorganisms activity on $\mathrm{CO}$ kinetics production. Additionally, this article, for the first time, comprehensively explains the effect of these parameters on the kinetics of CO production under biotic and abiotic conditions. The main research hypothesis and the driving force behind this work is the belief that understanding the kinetics of $\mathrm{CO}$ production during aerobic waste biostabilization and the factors influencing it will allow controlling of this production in the future. We believe that the ability to predict the course of $\mathrm{CO}$ formation during the process and the total amount of produced gas will enable the development of models to reduce the negative impact of $\mathrm{CO}$ not only on the environment but also on human health. The uniqueness of the presented research is also emphasized by the fact that there are no sources dealing with this topic in the literature, which makes us pioneers in this area. Due to the aspects of occupational health and safety, our results may be of interest to representatives of industry, mainly owners of composting plants. The presented data may also become a stimulus for the development of industrial and engineering solutions aimed at, on the one hand, ensuring the safety of human health and life, but also limiting the negative impact of the composting process on the environment. Additionally, due to environmental aspects, these results may be relevant to politicians, environmentalists, and other researchers dealing with the emission of harmful gases. The perspective of using the results presented in this paper is therefore important not only on a regional scale, concerning individual composting plants, but—what is important—on a global scale. 


\section{Materials and Methods}

\subsection{Waste Characteristics}

Three fractions of waste were tested: dairy cattle manure, grass clippings, and pine sawdust. For the process of aerobic biostabilization of waste, it is recommended to keep the material moisture at $40-60 \%$ [31]. In order to obtain this parameter equal to $\sim 59 \%$, groups of waste used in the experiment were mixed in a mass ratio of 1:1:1. All samples were analyzed before and after the process for moisture and volatile solids (VS) content [32]. The respirometry activity (a.k.a. $\mathrm{AT}_{4}$ ) of cattle manure, grass clippings, pine sawdust separately, and of the biowaste mixture were determined according to $[33,34]$.

\subsection{The Experiment Design and Procedure}

The experiments were performed in laboratory conditions, in fixed temperature bioreactors, in triplicates, at the following temperatures: $10,25,30,37,40,50,60$, and $70{ }^{\circ} \mathrm{C}$, in sterile (abiotic) and non-sterile (biotic) conditions. For each bioreactor, 50 55 g of mixed biowaste was placed in the climatic chamber (POL-EKO, model ST-3, Wodzisław Ślaski, Poland) under constant temperature conditions. The climatic chamber also shielded the bioreactors from natural light. The tests were carried out in $1 \mathrm{~L}$ bioreactors. The tyndalization method was used for biowaste sterilization-material in reactors was placed in the dryer for $1 \mathrm{~h}$ at $105^{\circ} \mathrm{C}, 3$ times with $24 \mathrm{~h}$ intervals. Figure 1 shows the experimental set-up.

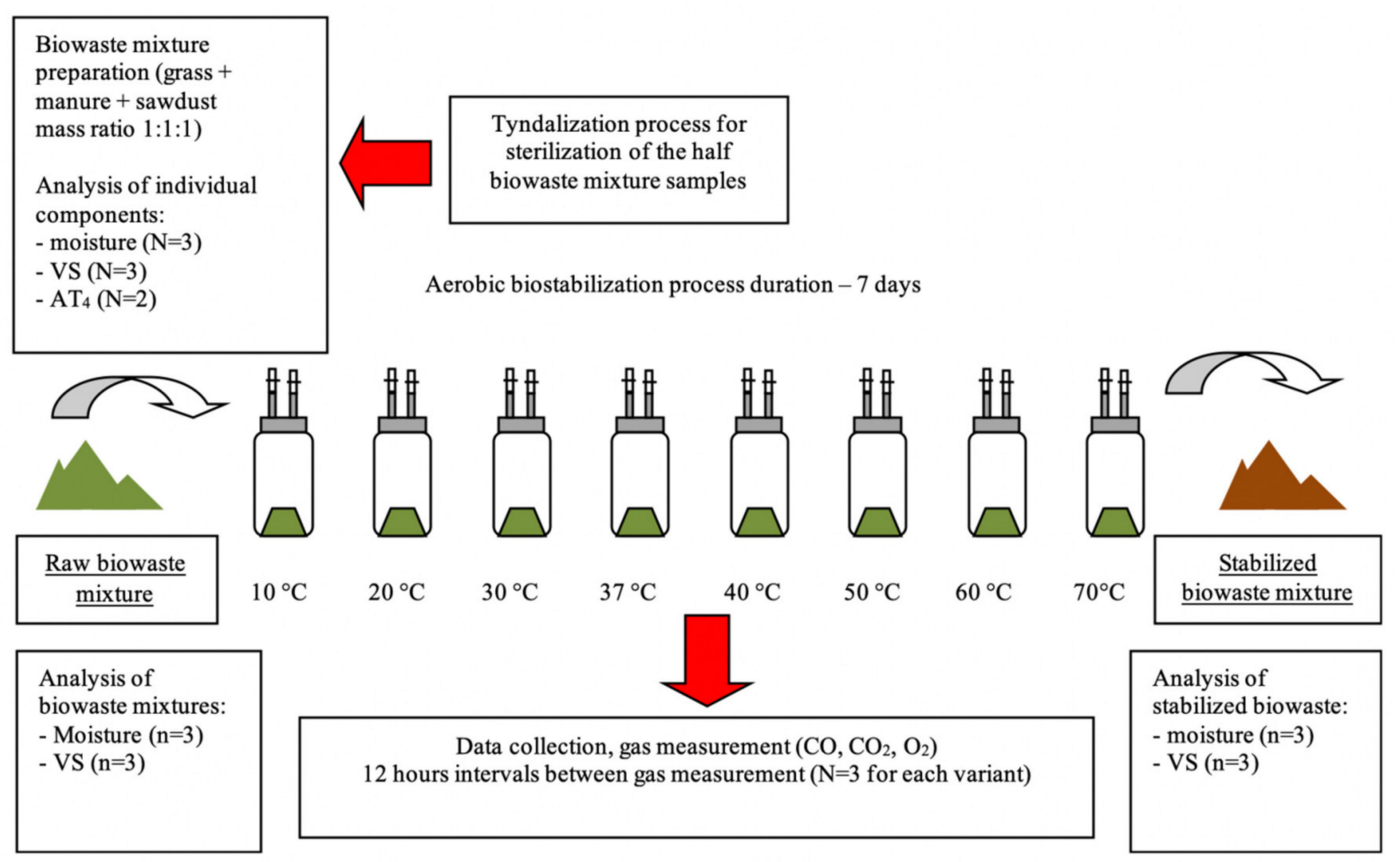

Figure 1. Scheme of the experimental set-up.

\subsection{Gas Production Monitoring}

The concentrations of $\mathrm{CO}, \mathrm{O}_{2}$, and $\mathrm{CO}_{2}$ formed inside the reactors were monitored at a frequency of $12 \mathrm{~h}$, starting at the twelfth hour from the set up of the experiment after incubating the reactors at a constant temperature. Measurements were carried out using a factory-calibrated Kimo KIGAZ 200 (Kimo Instruments, Chevry-Cossigny, France) exhaust gas analyzer. In each case, three replicates were performed, measuring the gas concentrations for $\sim 50 \mathrm{~s}$ until the indicated values stabilized. The aerobic conditions in bioreactors' headspace were obtained by ventilation with the application of sterile filters (to keep sterile conditions in abiotic variants) during each gas measurement. Specific information about gas production measurement methods, air supplied to the process is described in our previous study [4]. 


\subsection{CO Production Kinetics Determination}

Data for kinetic analysis were analyzed by excluding the lag-phase [35]. Nonlinear least squares regression was used to determine the kinetic parameters of $\mathrm{CO} \& \mathrm{CO}_{2}$ production and $\mathrm{O}_{2}$ consumed. The cumulative curves of $\mathrm{CO} \& \mathrm{CO}_{2}$ production and $\mathrm{O}_{2}$ consumption concerning biowaste dry mass (d.m.) were determined [36]. The zero-order and 1st-order reaction models were compared. The zero-order equation for gas production is:

$$
P=k \cdot t
$$

where:

$P$-total production or consumption $\left(\mathrm{CO}, \mathrm{CO}_{2}\right.$, or $\left.\mathrm{O}_{2}\right)$, (mg.g $\left.{ }^{-1} \mathrm{~d} . \mathrm{m}.\right)$,

$\mathrm{K}$-production or consumption rate $\left(\mathrm{CO}, \mathrm{CO}_{2}\right.$, or $\left.\mathrm{O}_{2}\right),\left(\mathrm{mg} \cdot \mathrm{g}^{-1} \mathrm{~d} \cdot \mathrm{m} \cdot \mathrm{h}^{-1}\right)$,

T-time, (h).

The 1st-order reaction equation for $\mathrm{CO}, \mathrm{CO}_{2}$, or $\mathrm{O}_{2}$ production or utilization is:

$$
P=P_{0} \cdot\left(1-e^{-k \cdot t}\right)
$$

where:

$P$ 一total production or consumption $\left(\mathrm{CO}, \mathrm{CO}_{2}\right.$, or $\left.\mathrm{O}_{2}\right)$, (mg.g $\left.{ }^{-1} \mathrm{~d} . \mathrm{m}.\right)$,

$P_{0}$-maximum production or consumption $\left(\mathrm{CO}, \mathrm{CO}_{2}\right.$, or $\left.\mathrm{O}_{2}\right)$, ( $\mathrm{mg} \cdot \mathrm{g}^{-1} \mathrm{~d} . \mathrm{m}$.),

$k$-production or consumption $\left(\mathrm{CO}, \mathrm{CO}_{2}\right.$, or $\left.\mathrm{O}_{2}\right)$ constant rate, $\left(\mathrm{h}^{-1}\right)$,

t-time, (h).

The $k$ and $P_{0}$, calculated from nonlinear regression, were used to calculate the average production or consumption rate $(r)$ of $\mathrm{CO}, \mathrm{CO}_{2}$, or $\mathrm{O}_{2}$ according to:

$$
r=k \cdot P_{0}
$$

where:

$r$-average production or consumption rate (r) of $\mathrm{CO}, \mathrm{CO}_{2}$, or $\mathrm{O}_{2},\left(\mathrm{mg} \cdot \mathrm{g}^{-1} \mathrm{~d} \cdot \mathrm{m} \cdot \mathrm{h}^{-1}\right)$.

The same procedure (Equations (6) and (7)) was applied for the respiration activity $\left(\mathrm{AT}_{4}\right)$ of the biowaste sample's characterization.

\subsection{Statistical Analysis}

Statistical analysis for the results was performed using the Statistica software 13.3 (TIBCO Software Inc., Palo Alto, CA, USA). Parametric tests (unequal-variance analysis and Tukey's post-hoc test at the significance level $\alpha=0.05$ ) were used to compare the differences between variants. Kinetic model parameters were statistically verified by estimating the value of the determination coefficient $R^{2}$ and Akaike information criterion (AIC) according to the following formula [37]:

$$
A I C=n \log \left(\frac{\sum \hat{e}_{i}^{2}}{n}\right)+2 K
$$

where:

$\hat{e}_{i}$ - the estimated residuals for a particular candidate model,

$K$-total number of estimated regression parameters. 


\section{Results}

\subsection{Material Properties before and after Composting}

The initial moisture content in the biowaste mixture was $\sim 59 \%$. The final moisture content depended on the composting temperature. In general, for the $10 \sim 40{ }^{\circ} \mathrm{C}$ range, the final moisture content fluctuated near the initial value of $59 \%$. For $25^{\circ} \mathrm{C}$, the moisture content decreased in the abiotic variant to $58 \%$, while it increased to almost $62 \%$ for the biotic variant. For $30{ }^{\circ} \mathrm{C}$, a decrease of moisture content in both variants was observed to $53 \%$ \& $57 \%$ in abiotic \& biotic variants, respectively. At $37^{\circ} \mathrm{C}$ in the case of abiotic variant, the significant $(p<0.05)$ drop of the water content compared to the abiotic conditions at 25,60 , and $70{ }^{\circ} \mathrm{C}$ (Figure 2a), but less significant than at $30{ }^{\circ} \mathrm{C}(56.5 \%$ for abiotic and $58 \%$ for biotic conditions). At $40{ }^{\circ} \mathrm{C}$, the differences between abiotic and biotic variants were significant $(p<0.05)$, and the water content amounted to $57 \%$ and $60 \%$, respectively.
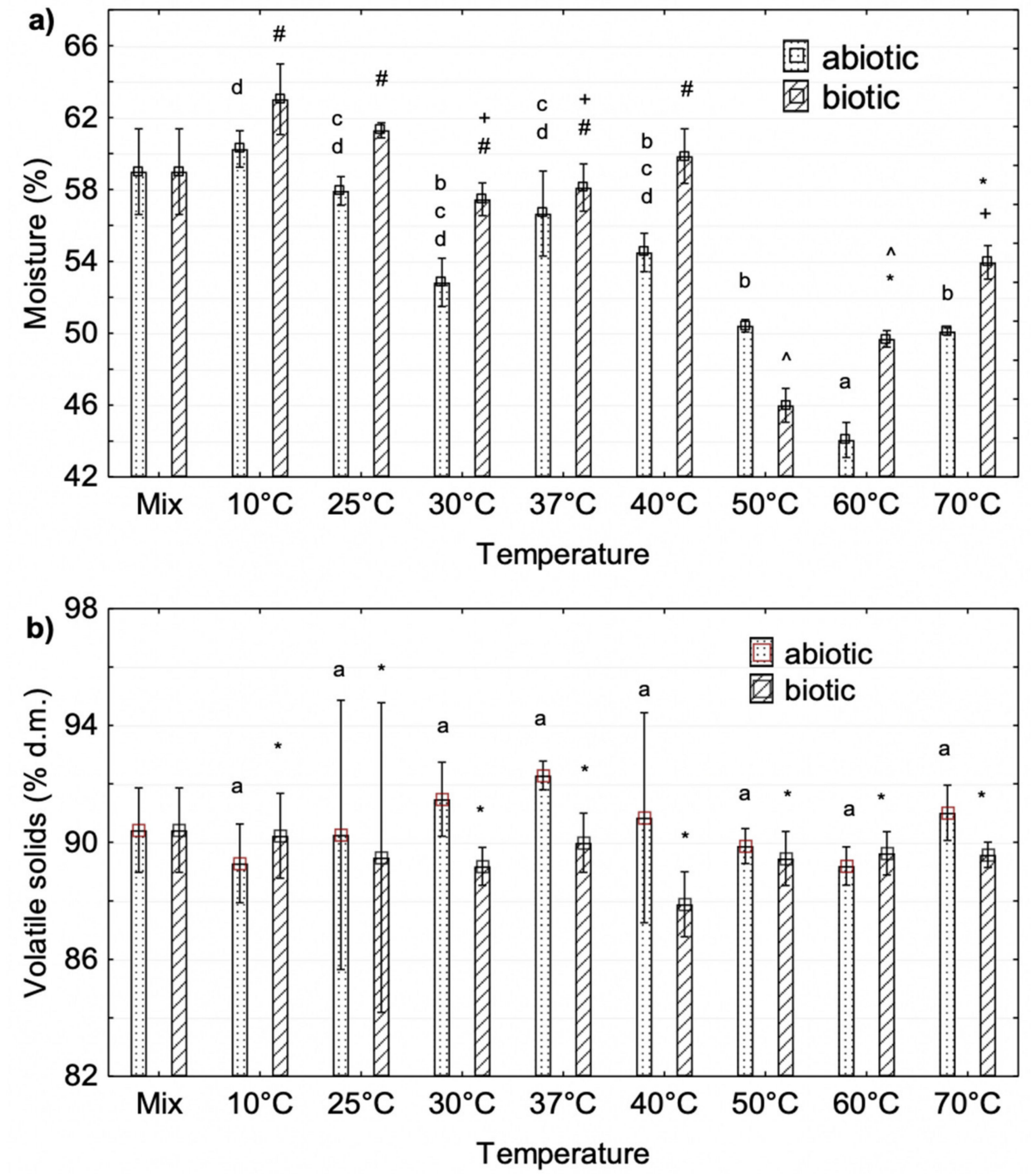

Figure 2. (a) Moisture content in biowaste (Mix-before the experiment) and residual biowaste after biowaste aerobic biostabilization under biotic and abiotic conditions under different thermal conditions,(b) volatile solids content in biowaste (Mix-before the experiment); letters and symbols $\left(\mathrm{a}, \mathrm{b}, \mathrm{c}, \mathrm{d},{ }^{*},+, \#\right)$ indicate homogeneity group according to Tukey'stest at significance level $p<0.05$ (abiotic and biotic variant, respectively). The error bars are showing $+/-$ standard deviation around the mean. 
Composting above $50^{\circ} \mathrm{C}$ significantly $(p>0.05)$ reduced the water content in all variants, below the optimum value of $59 \%$. At $60{ }^{\circ} \mathrm{C}$, the final moisture content was $40 \%$ and $49 \%$ for the abiotic and the biotic variant, respectively. It was the highest moisture loss, which may indicate the highest intensity of the process at this temperature. In the abiotic variant, a significant difference $(p>0.05)$ was observed between $60 \& 10,25 \& 30^{\circ} \mathrm{C}$ and between $70 \& 10,25,30,37,40$ and $50{ }^{\circ} \mathrm{C}$ (Figure 2a). Composting at $70{ }^{\circ} \mathrm{C}$ resulted in moisture content drop up to $50 \%$ in abiotic and $54 \%$ in the biotic variant. Significant differences $(p>0.05)$ were observed between the abiotic variant at $60 \& 70$ and 10 , $25,30,37,40, \& 50^{\circ} \mathrm{C}$ (Figure 3).
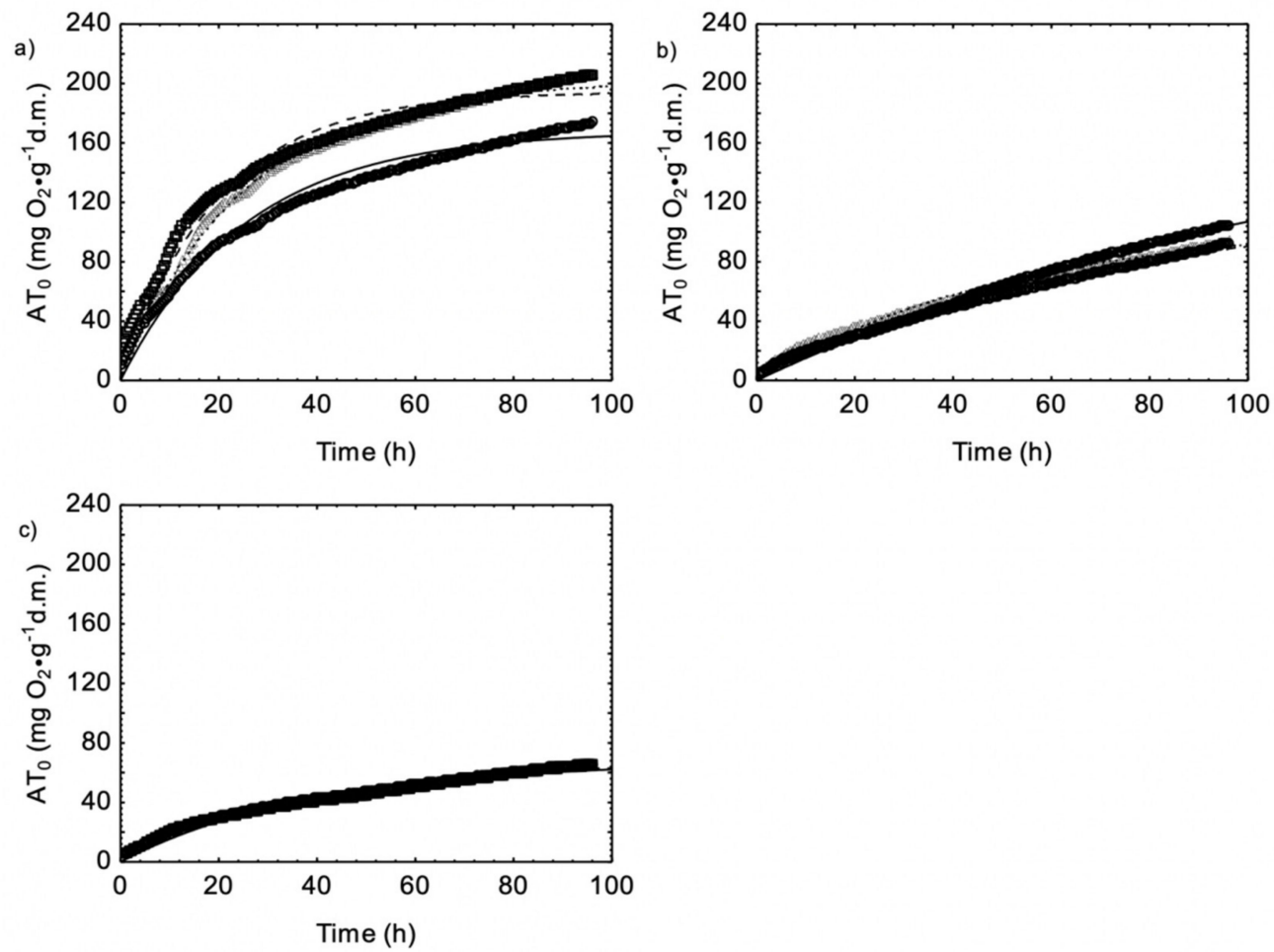

Figure 3. The respiration activity (AT0) of substrates $(\mathrm{N}=3)$ and waste $\operatorname{mix}(\mathrm{N}=2)$; $(\mathbf{a})$ grass, $(\mathbf{b})$ manure, (c) mixture (different lines on figures mean repetitions).

The prepared biowaste mixture was characterized by a high content of volatile solids $(\sim 90 \%$ d.m., Figure 2b). However, no significant differences $(p>0.05)$ were observed during the 1-week aerobic biostabilization of the mixture (Figure 2b). In most variants, the content of organic matter was slightly numerically lower (not statistically significant) in non-sterilized biowaste in comparison to the sterilized under the same thermal conditions, which could be due to the activity of microorganisms under biotic conditions. The slight decrease (not statistically significant) in organic compounds is also due to the short process time $(7 \mathrm{~d})$. The highest $(p<0.05)$ differences between abiotic and biotic variants were observed at $30 \& 40{ }^{\circ} \mathrm{C}$ ( $91.5 \%$ vs. $88.5 \%$, \& $91 \%$ vs. $88 \%$, respectively) (Figure 2 b).

Both two types of substrates (grass and manure) and the resulting biowaste mixture used in experiments were characterized by high respiration activity (Figure 3). The highest activity was obtained in the case of grass (188 $\mathrm{mg} \mathrm{O}_{2} \cdot \mathrm{g}^{-1} \mathrm{~d} . \mathrm{m}$.), followed by manure (141 $\mathrm{mg} \mathrm{O}_{2} \cdot \mathrm{g}^{-1} \mathrm{~d} . \mathrm{m}$.), and biowaste mixture (67.5 $\mathrm{mg} \mathrm{O}_{2} \cdot \mathrm{g}^{-1} \mathrm{~d}$.m.) (Table 1). The lowest $\mathrm{AT}_{4}$ value for biowaste mixture was caused by the addition of inert sawdust. The kinetic rate constant for the $\mathrm{O}_{2}$ demand of the obtained waste mixture was $0.026 \mathrm{~h}^{-1}$ (Table 1$)$. 
Table 1. The kinetic parameters of respiration activity for grass, manure, and biowaste mixture (shown in Figure 3).

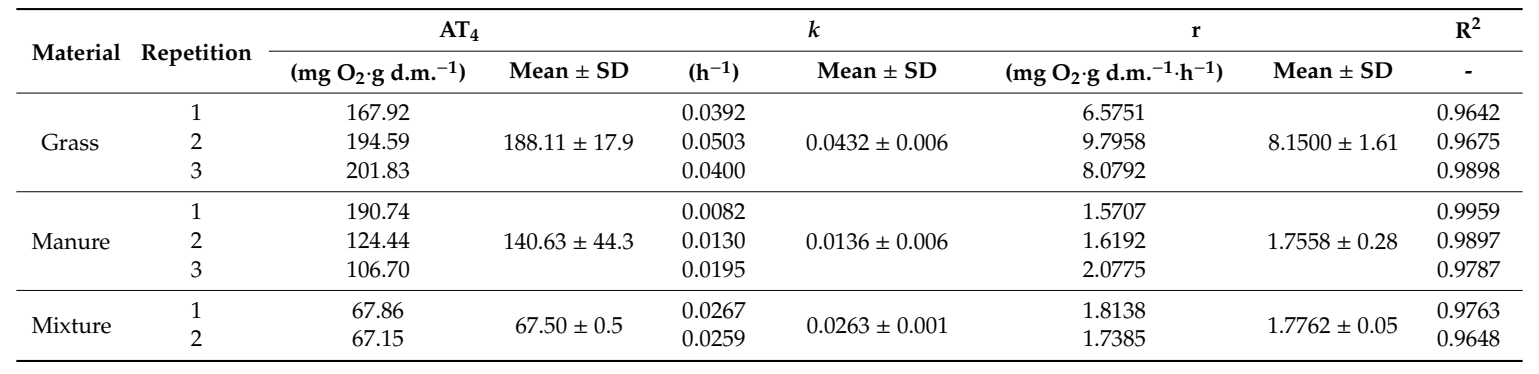

\subsection{Dynamics of $\mathrm{O}_{2}$ Consumption and $\mathrm{CO}_{2}$ Production during Biowaste Aerobic Biostabilization}

The $\mathrm{O}_{2}$ consumption and $\mathrm{CO}_{2}$ production were higher in all biotic variants compared with abiotic. This also indicated the successful sterilization process driven by biological \& thermochemical mechanisms in biotic variants, while only thermochemical in abiotic. $\mathrm{O}_{2}$ consumption in the biotic variant at $10^{\circ} \mathrm{C}$ was $56.2 \mathrm{mg} \mathrm{O} \cdot \mathrm{g}^{-1} \mathrm{~d} . \mathrm{m}$. (Figure 4a), while the amount of $\mathrm{CO}_{2}$ produced during the experiment reached $72.8 \mathrm{mg} \mathrm{CO} \cdot \mathrm{g}^{-1} \mathrm{~d} . \mathrm{m}$. (Figure $5 \mathrm{a}$ ). At the same time, the amount of $\mathrm{CO}_{2}$ produced in the abiotic variant was much lower and amounted to $4.04 \mathrm{mg} \mathrm{CO} \mathrm{CO}^{-1} \mathrm{~d} \cdot \mathrm{m}$ (Figure 5a). Larger amounts of $\mathrm{CO}_{2}$ generated and $\mathrm{O}_{2}$ consumed were observed at $20{ }^{\circ} \mathrm{C}$ (Figures $4 \mathrm{~b}$ and $5 \mathrm{~b}$ ). The total amount of $\mathrm{O}_{2}$ consumed by microorganisms during $168 \mathrm{~h}$ was $6.03 \mathrm{mg} \mathrm{O} \cdot \mathrm{O}^{-1} \mathrm{~d} . \mathrm{m}$. under abiotic conditions and $112 \mathrm{mg} \mathrm{O} \mathrm{O}_{2} \cdot \mathrm{g}^{-1} \mathrm{~d}$.m. in the biotic variant. At $30^{\circ} \mathrm{C}$, a further increase in $\mathrm{O}_{2}$ consumed was observed (Figure $4 \mathrm{c}$ ). The amount of $\mathrm{CO}_{2}$ produced at this temperature was $6.75 \mathrm{mg} \mathrm{CO} \mathrm{CO}_{2} \cdot \mathrm{g}^{-1} \mathrm{~d}$.m. in abiotic and $174 \mathrm{mg} \mathrm{CO} 2 \cdot \mathrm{g}^{-1} \mathrm{~d} . \mathrm{m}$. in biotic variant (Figure $5 \mathrm{c}$ ). In the case of abiotic conditions, the effect of time was not statistically significant $(p>0.05)$ for the observed in $\mathrm{CO}_{2}$ production and $\mathrm{O}_{2}$ consumption at 10,25 , and $30^{\circ} \mathrm{C}$, indicating that these variants belonged to the same homogeneous group.

A significant statistical difference was observed only at the end of the process at $37^{\circ} \mathrm{C}(132 \sim 168 \mathrm{~h})$ (Table S3.12-S3.15, Supplementary Materials). A different outcome was noted in the case of abiotic conditions at 30 and $40{ }^{\circ} \mathrm{C}$, i.e., much higher amounts of $\mathrm{O}_{2}$ consumed and $\mathrm{CO}_{2}$ produced in the case of $40{ }^{\circ} \mathrm{C}$, a significant difference $(p<0.05)$ between variants, notably visible at the end of the process.

The peak of $\mathrm{CO}_{2}$ produced (205 $\mathrm{mg} \mathrm{CO} 2 \cdot \mathrm{g}^{-1} \mathrm{~d} . \mathrm{m}$.) and $\mathrm{O}_{2}$ consumed $\left(160 \mathrm{mg} \mathrm{O}_{2} \cdot \mathrm{g}^{-1} \mathrm{~d} . \mathrm{m}\right)$ was observed at $40{ }^{\circ} \mathrm{C}$ in the biotic variant (Figures $4 \mathrm{e}$ and 5e). The values obtained showed significant differences $(p<0.05)$ for most of the temperatures and belonged to a separate homogeneous group at most of the time of the experiment. At $50{ }^{\circ} \mathrm{C}$, a decrease in the amount of $\mathrm{CO}_{2}$ produced (153 $\left.\mathrm{mg} \mathrm{CO} \mathrm{CO}_{2} \cdot \mathrm{g}^{-1} \mathrm{~d} . \mathrm{m}\right)$ and $\mathrm{O}_{2}$ consumed $\left(130 \mathrm{mg} \mathrm{O} \mathrm{O}_{2} \cdot \mathrm{g}^{-1} \mathrm{~d} . \mathrm{m}\right)$ were observed (Figures $4 \mathrm{f}$ and $5 \mathrm{f}$ ) in biotic variants in comparison to $40^{\circ} \mathrm{C}$.

At $60^{\circ} \mathrm{C}$, a decrease in the amount of $\mathrm{CO}_{2}$ produced $\left(116 \mathrm{mg} \mathrm{CO} \cdot \mathrm{CO}^{-1} \mathrm{~d} . \mathrm{m}\right)$ and $\mathrm{O}_{2}$ consumed (101 $\mathrm{mg} \mathrm{O}_{2} \cdot \mathrm{g}^{-1} \mathrm{~d}$.m) under biotic conditions were observed (Figures $4 \mathrm{~g}$ and $5 \mathrm{~g}$ ). The highest amount of $\mathrm{CO}_{2}$ produced $46 \mathrm{mg} \mathrm{CO} \cdot \mathrm{g}^{-1} \mathrm{~d} . \mathrm{m}$ in the entire experiment was observed at abiotic conditions under $60{ }^{\circ} \mathrm{C}$ (Figure 5g). The amount of $\mathrm{O}_{2}$ consumed and $\mathrm{CO}_{2}$ produced at $70{ }^{\circ} \mathrm{C}$ was very low (below $20 \mathrm{mg} \mathrm{CO} \cdot \mathrm{g}^{-1} \mathrm{~d} . \mathrm{m}$ ) and numerically similar regardless of the conditions (Figures $4 \mathrm{~h}$ and $5 \mathrm{~h}$ ).

\subsection{Kinetics of CO Production during Biowaste Aerobic Biostabilization}

The accumulated amount of $\mathrm{CO}$ generated during the experiment at various temperatures is shown in Figure 6. Table S3.3 (Supplementary Materials) presents the best-fit reaction kinetics model (0- or 1st-order) selected based on the coefficient of determination $\left(\mathrm{R}^{2}\right)$ and Akaike information criterion (AIC). The amount of $\mathrm{CO}$ produced at $10^{\circ} \mathrm{C}$ was $7.23 \mu \mathrm{g} \mathrm{CO} \cdot \mathrm{g}^{-1} \mathrm{~d} . \mathrm{m}$. under abiotic and $16.5 \mu \mathrm{g} \mathrm{CO} \cdot \mathrm{g}^{-1} \mathrm{~d} . \mathrm{m}$. biotic conditions (Figure 6a). At $20^{\circ} \mathrm{C}, \mathrm{CO}$ production was higher for both abiotic and biotic variants, and the final value was slightly higher for the abiotic $\left(26.7 \mu \mathrm{g} \mathrm{CO} \cdot \mathrm{g}^{-1} \mathrm{~d} . \mathrm{m}\right.$.) compared to $25.9 \mu \mathrm{g} \mathrm{CO} \cdot \mathrm{g}^{-1} \mathrm{~d} . \mathrm{m}$. for biotic (Figure $6 \mathrm{~b}$ ). At $30{ }^{\circ} \mathrm{C}$, the $\mathrm{CO}$ production was $17.5 \mu \mathrm{g} \mathrm{CO} \cdot \mathrm{g}^{-1} \mathrm{~d} . \mathrm{m}$. (abiotic) and $21.5 \mu \mathrm{g} \mathrm{CO} \cdot \mathrm{g}^{-1} \mathrm{~d} . \mathrm{m}$. (biotic) (Figure $6 \mathrm{c}$ ). Higher $\mathrm{CO}$ production 
was observed at $37^{\circ} \mathrm{C}$ (Figure 6d), especially for abiotic variant $43.4 \mu \mathrm{g} \mathrm{CO} \cdot \mathrm{g}^{-1} \mathrm{~d} . \mathrm{m}$. compared to $31.4 \mathrm{~g} \mathrm{CO} \cdot \mathrm{g}^{-1} \mathrm{~d} . \mathrm{m}$. under biotic conditions. The opposite situation was observed during biostabilization at $40^{\circ} \mathrm{C}$ (Figure 6e).
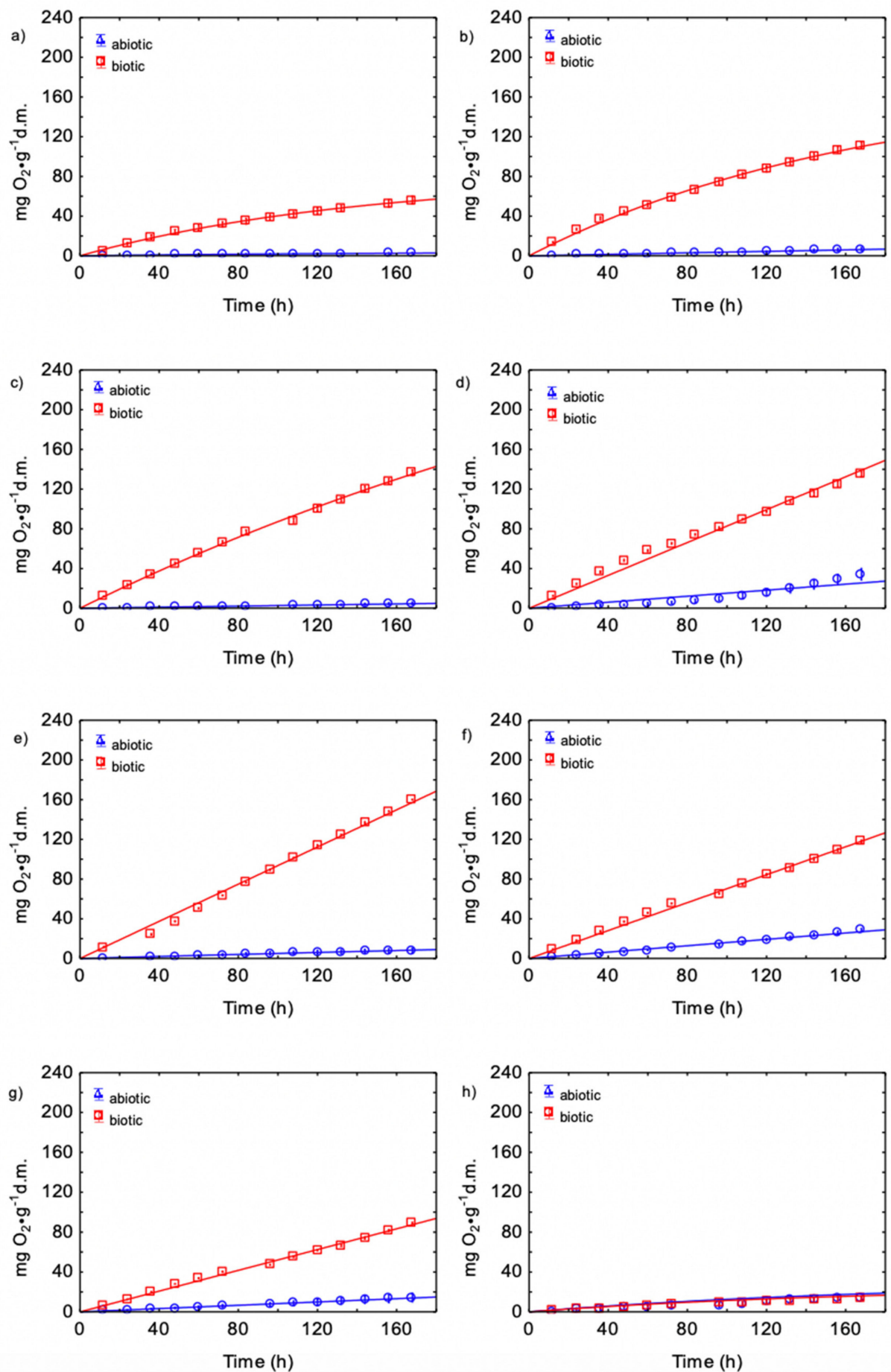

Figure 4. Cumulative $\mathrm{O}_{2}$ consumption depending on the temperature under abiotic and biotic conditions under different fixed temperatures (a) $10^{\circ} \mathrm{C}$, (b) $20^{\circ} \mathrm{C},(\mathbf{c}) 30^{\circ} \mathrm{C}$, (d) $37^{\circ} \mathrm{C},(\mathbf{e}) 40^{\circ} \mathrm{C},(\mathbf{f}) 50^{\circ} \mathrm{C}$, (g) $60^{\circ} \mathrm{C}$, (h) $70{ }^{\circ} \mathrm{C}$. The error bars are showing $+/-$ standard deviation around the mean. Raw data are shown in Tables S1.1 and S1.2 (Supplementary Materials, sheet 1). The kinetic values are shown in Table S2.1 (Supplementary Materials, sheet 4). Equations used in figures are shown in Table A1. The Tukey test $p<0.05$ are shown in Tables S3.1-S3.28 (Supplementary Materials, sheet 6). 

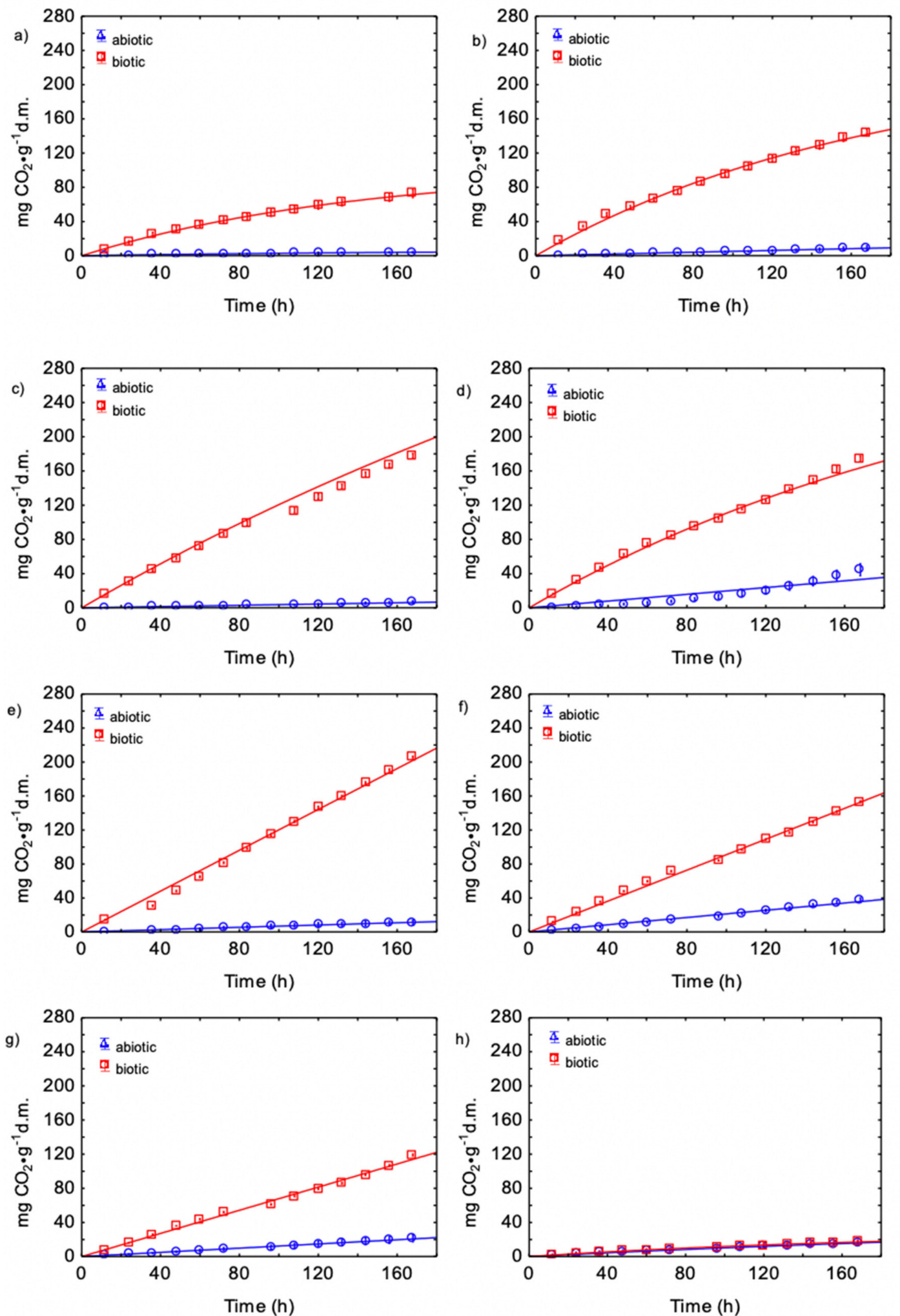

Figure 5. Cumulative $\mathrm{CO}_{2}$ production depending on the temperature under abiotic and biotic conditions under different fixed temperatures (a) $10^{\circ} \mathrm{C},(\mathbf{b}) 20^{\circ} \mathrm{C}$, (c) $30^{\circ} \mathrm{C},(\mathbf{d}) 37^{\circ} \mathrm{C},(\mathbf{e}) 40^{\circ} \mathrm{C},(\mathbf{f}) 50{ }^{\circ} \mathrm{C},(\mathrm{g}) 60^{\circ} \mathrm{C}$, (h) $70^{\circ} \mathrm{C}$. The error bars are showing $+/-$ standard deviation around the mean. Raw data are shown in Tables S1.3 and S1.4 (Supplementary Materials, sheet 2). The kinetic values are shown in Table S2.2 (Supplementary Materials, sheet 5). Equations used in figures are shown in Table A1. The Tukey test $p<0.05$ are shown in Tables S3.29-S3.56 (Supplementary Materials, sheet 8). 

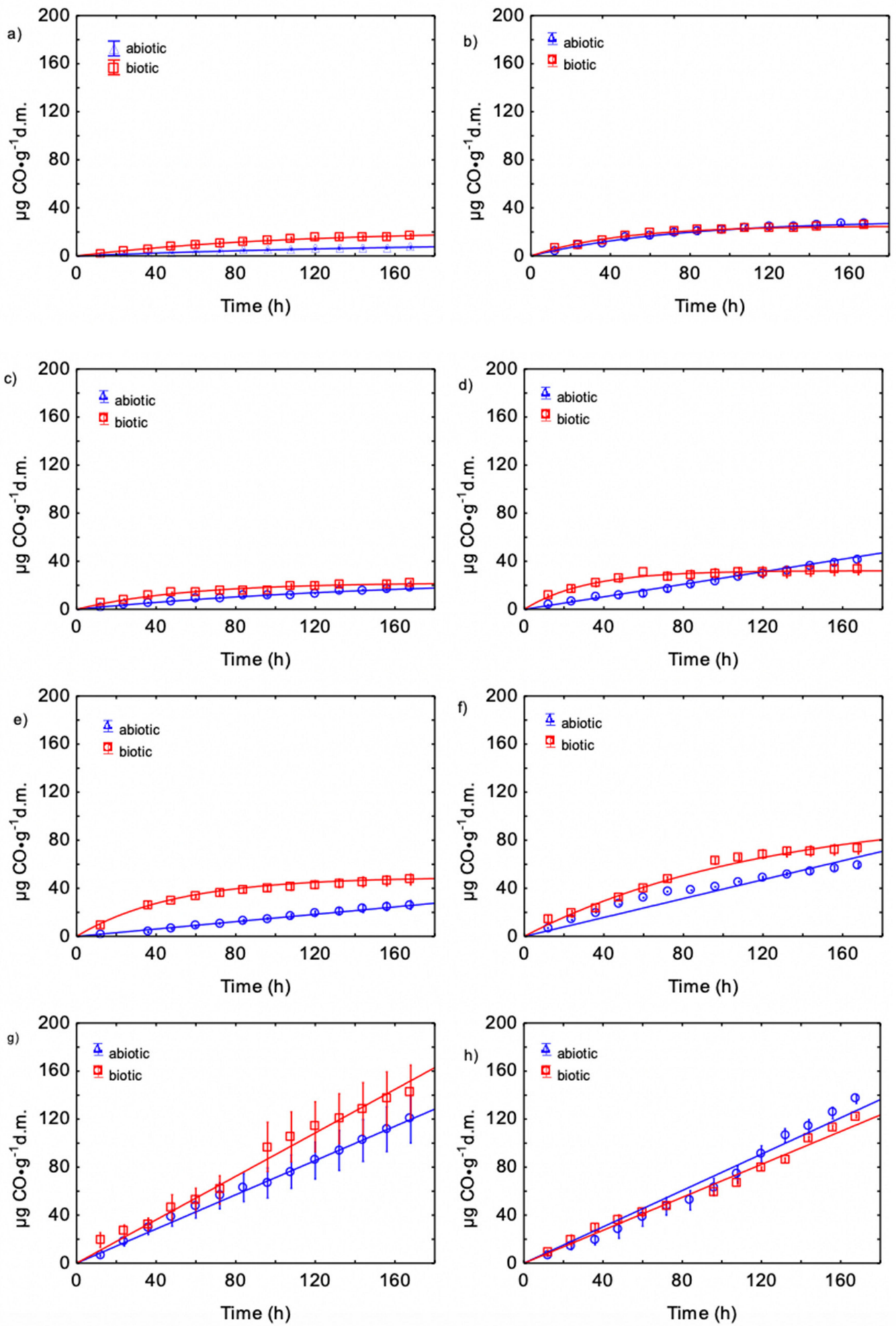

Figure 6. Cumulative $\mathrm{CO}$ production depending on the temperature under abiotic and biotic conditions under different fixed temperatures (a) $10^{\circ} \mathrm{C}$, (b) $20^{\circ} \mathrm{C}$, (c) $30^{\circ} \mathrm{C}$, (d) $37^{\circ} \mathrm{C}$, (e) $40^{\circ} \mathrm{C}$, (f) $50{ }^{\circ} \mathrm{C}$, (g) $60^{\circ} \mathrm{C}$, (h) $70^{\circ} \mathrm{C}$. The error bars are showing $+/-$ standard deviation around the mean. Raw data are shown in Tables S1.5 and S1.51 (Supplementary Materials, sheet 3). The kinetic values are shown in Table S2.3 (Supplementary Materials, sheet 6). Equations used in figures are shown in Table A1. The Tukey test $p<0.05$ are shown in Tables S3.57-S3.84 (Supplementary Materials, sheet 9). 
Increasing temperature resulted in a further increase in $\mathrm{CO}$ production at $50{ }^{\circ} \mathrm{C}$ to $58.8 \mu \mathrm{g} \mathrm{CO} \cdot \mathrm{g}^{-1} \mathrm{~d} . \mathrm{m}$. (abiotic) and $73.0 \mu \mathrm{g} \mathrm{CO} \cdot \mathrm{g}^{-1} \mathrm{~d} . \mathrm{m}$. (biotic), at $60^{\circ} \mathrm{C}$ to $120 \mu \mathrm{g} \mathrm{CO} \cdot \mathrm{g}^{-1} \mathrm{~d} . \mathrm{m}$. (abiotic) and $115 \mu \mathrm{g} \mathrm{CO} \cdot \mathrm{g}^{-1} \mathrm{~d} . \mathrm{m}$. (biotic), and at $70^{\circ} \mathrm{C}$ to $137 \mu \mathrm{g} \mathrm{CO} \cdot \mathrm{g}^{-1} \mathrm{~d} . \mathrm{m}$. (abiotic) and $122 \mu \mathrm{g} \mathrm{CO} \cdot \mathrm{g}^{-1} \mathrm{~d} . \mathrm{m}$. (biotic) (Figure 6f). Significant differences $(p<0.05)$ in abiotic variants were observed between $\mathrm{CO}$ production under $10,20,30,37 \& 40^{\circ} \mathrm{C}$ and temperatures of $50,60 \& 70{ }^{\circ} \mathrm{C}$, which indicates that the temperature of $40^{\circ} \mathrm{C}$ is a threshold value above which the CO production significantly $(p<0.05)$ increases. In biotic variants, significant differences were noted between the temperature of $10,20,30$, \& $37^{\circ} \mathrm{C}$ and the temperature of $50,60 \& 70^{\circ} \mathrm{C}$ for up to $60 \mathrm{~h}$ of experiment. At $70{ }^{\circ} \mathrm{C}$, the differences were the same in both variants, due to the lethal effects of high temperatures on bacteria.

\subsection{Kinetics of $\mathrm{CO}_{2}$ and $\mathrm{CO}$ Production and $\mathrm{O}_{2}$ Consumption during Biowaste Aerobic Biostabilization}

Kinetics analyses of the production of $\mathrm{CO} \& \mathrm{CO}_{2}$ and $\mathrm{O}_{2}$ consumption were performed. The obtained results of $\mathrm{O}_{2}$ consumption (Table S2.1, Supplementary Materials) and $\mathrm{CO}_{2}$ production (Table S2.2, Supplementary Materials) during the biowaste aerobic biostabilization process differed significantly depending on the variant and temperature. Particularly high $\mathrm{O}_{2}$ consumption and $\mathrm{CO}_{2}$ production were observed in biotic variants.

The nature of $\mathrm{O}_{2}$ consumption in the low-temperature range from 10 to $30^{\circ} \mathrm{C}$ in both abiotic and biotic variants was nonlinear (Table S2.1, Supplementary Materials). At higher temperatures from 37 to $60^{\circ} \mathrm{C}$, the cumulative curves had linear character, while in the case of $70^{\circ} \mathrm{C}$, the 1 st-order model better fitted to the results (Table A1). In the case of $\mathrm{CO}_{2}$ production, a clear distinction into abiotic (mostly with a linear trend) and biotic (1st-order model) (Table S2.2, Supplementary Materials, Table A1) was observed. In the case of $\mathrm{CO}$ production, it was difficult to demonstrate one specific type of trend. At temperatures up to $30^{\circ} \mathrm{C}$, all analyzed samples followed the 1st-order model (Table S3.3, Supplementary Materials). At $37 \sim 40^{\circ} \mathrm{C}$, two different trends were observed, i.e., the linear for abiotic variants and the 1st-order for biotic conditions (Table A1). At $50{ }^{\circ} \mathrm{C}$, all variants were characterized by the 1storder model, while at $60 \sim 70{ }^{\circ} \mathrm{C}$, the $\mathrm{CO}$ production kinetics had an evident linear character (Table A1).

The $\mathrm{k}$ value had typical values for the composting process, $0.002-0.15\left(\mathrm{~d}^{-1}\right)$ [38]. It was noted that $\mathrm{O}_{2}$ consumption in the temperature range up to was significantly lower in abiotic variants. Above $40{ }^{\circ} \mathrm{C}$, the $\mathrm{k}$ values were similar (Table S2.1, Supplementary Materials) both under biotic and abiotic conditions.

For $\mathrm{CO}_{2}$ production at temperatures up to $37^{\circ} \mathrm{C}$, a slightly higher $\mathrm{k}$ value was observed in biotic variants. In the range of $40 \sim 70^{\circ} \mathrm{C}$, slightly higher $\mathrm{k}$ and $\mathrm{r}_{\mathrm{CO} 2}$ values were observed in the case of abiotic variants (Table S2.2, Supplementary Materials, Figure A1). Both in $\mathrm{O}_{2}$ and $\mathrm{CO}$ production $\mathrm{r}_{\mathrm{O} 2}$ and $\mathrm{r}_{\mathrm{CO} 2}$ values were similar in abiotic conditions (Figure A1). In the case of $\mathrm{CO}$ production, the highest $\mathrm{k}$ values were observed in biotic variants ranging from 20 to $40{ }^{\circ} \mathrm{C}$, i.e., from 0.018 to $0.031 \mathrm{~h}^{-1}$. The $\mathrm{k}$ values were higher in all biotic variants than in abiotic (Table S3.3, Supplementary Materials; Figure A1).

\section{Discussion}

\subsection{Biowaste Properties}

The properties of biowaste and mixtures were shown and discussed in the previous article [4], Table S1 in Supplementary Materials. The experiment confirmed that the initial moisture content of dairy manure used to the experiment assumed typical values [38]. Organic matter content was similar to the previously observed by Fukumoto et al. [39] from $81.2 \%$ to $87.9 \%$ d.m. Similarly, the properties of grass did not differ significantly from the results available in the literature, i.e., moisture content of $70 \sim 80 \%$, organic content 70 90\% d.m. [40,41]. Due to the high moisture in both materials, it has been decided to add dried sawdust to obtain the optimal water content for the composting process $(\sim 60 \%$, according to [42]). The sawdust used was characterized by a relatively high content of organic 
substance compared to those used by Adhikari et al. [43], i.e., $75.0 \%$ compared to $53.7 \%$ d.m., which was the consequence of using fresh material.

Changes in moisture up to $5 \%$ in the material after the process observed during the present study are typical and consistent with data obtained earlier by other researchers. Sun et al. [44] explained this phenomenon by the process of water evaporation and its removal from headspace by the airflow. At lower temperatures $\left(<30^{\circ} \mathrm{C}\right)$, which do not allow for such intensive evaporation from the material, water is formed as a result of the decomposition of organic matter, both from chemical and microbiological sources [45]. This results in increased moisture of the waste [46,47].

The observed differences in the decomposition of the volatile solids between abiotic and biotic conditions were insignificant (especially at $>50{ }^{\circ} \mathrm{C}$ ), which may indicate that the thermochemical mechanism of organic matter decomposition dominated at higher temperatures. de Guardia et al. [48] noted that if the samples are similar to each other in organic matter content and moisture, their degradation is very similar, even despite different process conditions (temperature and moisture). Low organic matter decomposition could also indicate the influence of a large amount of hardly degradable lignocellulosic organic compounds from sawdust; even k value was similar to than proposed by [49] for the composting process. This sawdust constituted $33 \%$ of the sample, which is characterized by a high fraction of such substances [4].

Studies of various substrates made by Evangelou et al. [50] also demonstrated the high respiratory activity of microorganisms $\left(\mathrm{AT}_{4}\right)$ recorded in dairy manure and grass is the result of the high content of the easily-biodegradable organic substance (e.g., mono- and disaccharides, starch, proteins, and fats) in this biowaste. Sawdust was not tested for $\mathrm{AT}_{4}$ activity due to the use of dry material. Low humidity creates an unfavorable environment for the development of microorganisms. For this reason, the addition of dried pine sawdust (used to reduce moisture to optimal values) caused a decrease in $\mathrm{AT}_{4}$ to $67.5 \mathrm{mg} \mathrm{O} 2 \cdot \mathrm{g}^{-1} \mathrm{~d}$.m. in the biowaste mixture (Table 1).

All obtained results in the respiratory activity of microorganisms are typical for the type of material [51]. Dairy manure used for the tests showed a similar $\mathrm{AT}_{4}$ value to chicken manure 94.7 and $109 \mathrm{mg} \mathrm{O}_{2} \cdot \mathrm{g}^{-1} \mathrm{~d}$.m. [52] and to the organic fraction of municipal waste $90.9 \sim 119 \mathrm{mg} \mathrm{O}_{2} \cdot \mathrm{g}^{-1} \mathrm{~d} . \mathrm{m}$. [48].

Similarly to previous research, if the respiratory activity was following the 1st-order model, we also used for the determination of the kinetic parameters. Nonlinear estimations for almost all samples were characterized by a very high coefficient of determination $\left(R^{2}>0.96\right)$ (Table 1$)$. The highest rate constant was obtained for grass $\left(k=0.043 \mathrm{~h}^{-1}\right)$; lower $\mathrm{k}$ value was noted for manure $\left(\mathrm{k}=0.0136 \mathrm{~h}^{-1}\right)$ and biowaste mixture $\left(\mathrm{k}=0.026 \mathrm{~h}^{-1}\right)$. The rate constants were comparable with the values obtained by other researchers for plant materials such as leaves $\left(k=0.00129 \mathrm{~h}^{-1}\right)$, branches $\left(k=0.0025 \mathrm{~h}^{-1}\right)$, grass $\left(k=0.00125 \mathrm{~h}^{-1}\right)$, and food waste $\left(k=0.00044 \mathrm{~h}^{-1}\right)$ [53]. In studies made by Fernandez et al. [54], $\mathrm{k}$ was from 0.0009 to $0.0018 \mathrm{~d}^{-1}$. These values are in line with those proposed by Mason and Milke [49] for the composting process $\left(\mathrm{k}=0.0063 \mathrm{~h}^{-1}\right)$ and were higher than for organic waste.

\section{2. $\mathrm{O}_{2}$ Consumption, $\mathrm{CO}_{2}$ and $\mathrm{CO}$ Production during Biowaste Aerobic Biostabilization}

$\mathrm{CO}_{2}$ emissions are frequently used for estimating organic carbon decomposition [55]. In this research, it increased up to the 7th day of the process, but then a gradual decrease was observed. This phenomenon was also observed in laboratory conditions during composting garden waste [56,57] and in technical-scale analyzes when composting sewage sludge [44]. The amount of $\mathrm{CO}_{2}$ produced during the 48 days of the process was about $50,000 \mathrm{~g} \mathrm{CO}_{2} \cdot \mathrm{m}^{-2}$, with $20,000 \mathrm{~g} \mathrm{CO}_{2} \cdot \mathrm{m}^{-2}$ produced during the next five days of the process [44].

This high initial $\mathrm{CO}_{2}$ production is the result of the microbial activity that degrades easy-available volatile solids, such as simple sugars or organic acids [54]. This was confirmed by studies Nasini et al. [58], who observed a relationship between $\mathrm{CO}_{2}$ emission and the level of microbial activity during static composting in piles of waste from olive oil pressing. The involvement of aerobic microorganisms in the production of $\mathrm{CO}_{2}$ can also be seen in this research. For biotic variants, the amount of $\mathrm{CO}_{2}$ produced was much higher than for abiotic. Furthermore, the cumulative 
$\mathrm{CO}_{2}$ production was the highest at 30,37 , and $40^{\circ} \mathrm{C}$, while the lowest in extreme thermal conditions, i.e., 10 and $70{ }^{\circ} \mathrm{C}$. This may be due to the domination of mesophilic bacteria in the used biowaste mixture, for which the optimum temperature range is $30 \sim 40{ }^{\circ} \mathrm{C}$ [59]. Temperatures close to 10 and $70{ }^{\circ} \mathrm{C}$ caused inhibition of their metabolism, which affected the reduction of organic matter decompositions and the $\mathrm{CO}_{2}$ production.

Analyzes conducted by Sommer and Moller [60] allowed the observation of the relationship between $\mathrm{O}_{2}$ consumption and $\mathrm{CO}_{2}$ emission. The presence of one gas inhibits the occurrence of another. This tendency can also be seen in the results presented here (cumulative $\mathrm{O}_{2}$ consumption is inversely proportional to $\mathrm{CO}_{2}$ production). Additional confirmation is also the rapid decrease in the amount of $\mathrm{O}_{2}$ during the first 7 days observed earlier in the laboratory by Kulcu and Yaldiz [61] and in the technical-scale conditions [62]. Experiments carried out by [6] are also supported by the presented here findings. In the composting processes they analyzed, the initial decay in $\mathrm{O}_{2}$ content was simultaneous with an increase in the $\mathrm{CO}_{2}$ concentration in the material due to the decomposition of simple organic compounds. The correlation of $\mathrm{CO}_{2}$ production with $\mathrm{O}_{2}$ consumption in the present study and their dependence on the activity of microorganisms concerning temperature was also consistent with reports Puyuelo et al. [63]. They emphasized that temperature and $\mathrm{O}_{2}$ consumption are identified as key parameters for assessment of the microbial activity.

A characteristic feature of $\mathrm{CO}$ production during composting is its increased production in the early stages of the process. The researchers reported high concentrations of $\mathrm{CO}$ during composting of green waste with grass immediately after a few hours starting the experiment [19]. In the experiments of all of the cited authors $[4,7,19,64]$, the CO content decreased after a period of 1 to 2 weeks. In our previous research [6], $\mathrm{CO}$ emissions from the biostabilization process of organic fraction of municipal solid waste $\mathrm{CO}$ emission significantly decreased in the 3rd week of the full-scale experiment. This tendency is also visible in the present results. For process variants carried out at $10,20,30$, and $37^{\circ} \mathrm{C}$ after the initial increase in the amount of $\mathrm{CO}$ produced, the $\mathrm{CO}$ production stagnated (with $40{ }^{\circ} \mathrm{C}$ only in the case of biotic variant).

$\mathrm{CO}$ production rate decreased in the later stages of biostabilization can be explained by two factors. The first is the consumption of $\mathrm{CO}$ by bacteria as a result of oxidation $\mathrm{CO}$ to $\mathrm{CO}_{2}$ [5]. The second is based on the dependence between the content of $\mathrm{CO}$ and $\mathrm{O}_{2}$ in the biowaste matrix. $[3,7,19,64]$ reported the highest $\mathrm{CO}$ production under aerobic conditions. The $\mathrm{O}_{2}$ depletion causes a decrease in the level of $\mathrm{CO}$, and thus affects the increase in $\mathrm{CO}_{2}$ concentration, which could affect the results obtained.

In this study, the highest $\mathrm{CO}$ production was characterized by high-temperature biostabilization variants $\left(60,70\right.$, and $50^{\circ} \mathrm{C}$, respectively). The lowest $\mathrm{CO}$ production was obtained at 10 and $30^{\circ} \mathrm{C}$. These results are consistent with those obtained by [4]. In their experiment, the highest $\mathrm{CO}$ production was observed at 65 and $50^{\circ} \mathrm{C}$, while the lowest amounts of $\mathrm{CO}$ were generated during composting of green waste at $5{ }^{\circ} \mathrm{C}$.

\subsection{Kinetics of $\mathrm{O}_{2}$ Consumption, $\mathrm{CO}_{2}$ and $\mathrm{CO}$ Production during Biowaste Aerobic Biostabilization}

Many authors recognize the benefits of predicting gaseous products from composting, such as $\mathrm{CO}_{2}$ production and $\mathrm{O}_{2}$ consumption and other GHG, but still less data regarding $\mathrm{CO}$ kinetics production $[65,66]$. Knowledge of the kinetics of the composting process allows its modeling, which in turn could improve the optimization [67]. To date, researchers have proposed several models for process kinetics, mainly based on the physical and biochemical properties of composts [5]. Mathematical models most often refer to 0,1 st, or higher-order kinetics $[50,68]$. These models can effectively describe the evolution of changes in process parameters, such as mass balance, heat balance, organic matter degradation, $\mathrm{C}$ mineralization, or changes in the $\mathrm{C}, \mathrm{N}, \mathrm{P}, \mathrm{K}$ content $[53,69], \mathrm{O}_{2}$ demand, or $\mathrm{CO}_{2}$ production $[67,70]$. The proportion of nutrients have an extreme influence on compost properties [71]. No studies are presenting a full picture of the kinetics of COproduction as a function of the composting process temperature. Due to a gap in the literature, the comparison in this paper was made mainly based on other process parameters obtained by other researchers. The $\mathrm{CO}_{2}$ production stems from 
the oxidation of readily degradable carbon compounds, and consequently, from the nature of the substrates, $\mathrm{O}_{2}$, moisture, and microbial activity [72]. The $\mathrm{CO}_{2}$ emission rate is also an indicator of the rapid degradation of total organic matter and strong microbial activity [73]. The carbon mineralization of organic wastes follows a combined two-step kinetic: initial rapid phase1st-order followed by 0-order, slow phase [74], thus, the rationale to use of these two models to find kinetic parameters of composting. Results from this study confirmed that zero and 1st-order kinetic suits both for the production $\mathrm{CO}_{2}$ and $\mathrm{O}_{2}$ consumption (first stage of composting), which is confirmed with high $\mathrm{R}^{2}$ and low AIC results (Tables S2.1 and S2.2, Supplementary Materials). $\mathrm{CO}_{2}$ production and $\mathrm{O}_{2}$ consumption rate during biotic conditions were typical for the first stage of composting, as were observed by other researchers $[46,70,75]$. In the abiotic environment, $\mathrm{k}$ value was lower due to a lack of microorganism (sterilization process). $\mathrm{O}_{2}$ consumption rate was only a reason for thermochemical reactions inside easily biodegradable fraction. Hosseini and Aziz [76] confirmed that the increase in temperature in the composting pile results in an increase in the consumption rate at which chemical (hydrogen) bonds in substrate compounds like polysaccharides cellulose and lignocellulose are broken. As suggested by Ma et al. 2020 [77] this biodegradation, is made by complex enzymes and requires the synergistic action of various microorganisms. The same conditions influenced the $\mathrm{CO}$ production rate. We confirmed that the threshold value of $\mathrm{CO}$ production kinetics, below $40{ }^{\circ} \mathrm{C}$ is driven by biotic processes, while above $40^{\circ} \mathrm{C}$ by thermochemical. However, the net $\mathrm{CO}$ production above $40^{\circ} \mathrm{C}$ was limited by the biodegradation of thermochemically produced $\mathrm{CO}$. This is because the optimal temperature for most microorganisms is $38.5^{\circ} \mathrm{C}$, with a maximum from $63{ }^{\circ} \mathrm{C}$ to $\sim 67^{\circ} \mathrm{C}$, which, as the authors note, is not in line with the process temperature that we observed during composting in real condition, i.e., $60 \sim 70{ }^{\circ} \mathrm{C}$ [78]. It can be explained that the change in curvature observed is due to a change in the control regime of the oxidation reaction. Initially, it is governed by the biotic process (with a pseudo-first-order kinetics) until a temperature is reached in which a thermochemical regime governs (with zero-order kinetics). In the presented experiment, the confirmation of this trend was also noticed. In thermophilic conditions $>50^{\circ} \mathrm{C}$, the $\mathrm{CO}_{2}$ production was significantly reduced. However, the $\mathrm{CO}$ production increased with temperature, which confirms thermochemical nature, independent of microorganisms, at least at high temperatures. This observation is also confirmed with the kinetic model, i.e., $<50{ }^{\circ} \mathrm{C}$ the best-fit model is 1st-order kinetic, but $>50{ }^{\circ} \mathrm{C}$, the best-fit model was a 0 -order in both abiotic and biotic conditions (Table A1). This trend can be clearly observed in $\mathrm{r}_{\mathrm{O} 2}$ consumption and $\mathrm{r}_{\mathrm{CO} 2}$ production rate present in Figure A1. This information is true for 0 - and I-orderkinetics.

Although a higher $\mathrm{CO}$ production was observed at temperatures $<50^{\circ} \mathrm{C}$, the $\mathrm{k}$ and $\mathrm{CO}$ production ratewas always lower in abiotic conditions, even in thermophilic conditions, when it was similar for both variants. We also observed that in biotic conditions, where the maximum $\mathrm{CO}$ production was at $60{ }^{\circ} \mathrm{C}$, while the maximum $\mathrm{k}$ was at $37^{\circ} \mathrm{C}$. Some explanation can be elucidated from the results of Tang et al. [79] and Yu et al. [80], who noted that the $\mathrm{k}$ value of organic matter decomposition under thermophilic conditions was $\sim 20 \%$ higher than under mesophilic conditions, and the maximum thermophilic composting activity at temperatures in the range of $50 \sim 60{ }^{\circ} \mathrm{C}$. This was a result of thermochemical decomposition at high temperatures, as well as the microbial activity. It has been experimentally shown that the rate of microbial activity, as well as the process of hydrolysis, are closely related, and the relationship is as follows-the reaction rate increases in the range of 20 to $40 \sim 50{ }^{\circ} \mathrm{C}$, then after exceeding $50{ }^{\circ} \mathrm{C}$ begins to decrease rapidly (Figure A1) [74]. This effect is also clearly visible in this experiment and noticed in our previous research carried out on a technical scale [8,71] when the $\mathrm{k}$ value was the highest between the 2 nd and 4 th week of tests at a temperature in a pile is $>60{ }^{\circ} \mathrm{C}$.

Chen et al. [81] identified that key factors affecting the emissions of GHGs the most are: organic nitrogen $(\mathrm{Org} N, 33.0 \%)$, DOC $(20.5 \%), \mathrm{TN}(14.6 \%)$, and TOC $(10.2 \%)$. They believed that this characteristic of waste properties could also affect $\mathrm{CO}$ production. The results of this research create possibilities of predicting $\mathrm{CO}$ production during composting of organic waste, which can be useful, for example, to the modeling of $\mathrm{CO}$ concentrations and emissions in waste treatment plants [71]. 
Such modeling will allow the minimization of $\mathrm{CO}$ emissions from the process and the simultaneous use of engineering and technological solutions to optimize the decomposition of organic matter. Additionally, it will enable the development of recommendations and implementation of solutions limiting the negative impact of $\mathrm{CO}$ on the health of composting plant employees who have direct contact with the process. In the long term, the use of the predictive model to reduce $\mathrm{CO}$ emissions from the waste composting process will contribute to reducing air pollution and the associated adverse effects on public health, including the economy. Exposure to harmful compounds in the air is one of the main causes of pulmonary and cardiovascular diseases, resulting in the development of chronic diseases and premature mortality of the population. The reduction of these effects as a result of reducing pollutant emissions is defined as $75-85 \%$ of all estimated economic benefits of improving air quality [82]. So, it can be said that functioning in a healthier and cleaner environment will increase the standard of living.

Due to the limited knowledge in composting process $\mathrm{CO}$ production, we recommend more studies in this area. There are several pathways to explore, including composting trials with different feedstock, scaling up to larger composting volumes, exploring the influence of environmental stressors, and a more comprehensive assessment of the toxicity of emitted gases. This new data can improve mathematical models and help with the mitigation of $\mathrm{CO}$ production during composting and storage of organic waste. Another possibility is the production of $\mathrm{CO}$ and its use for the production of biorenewables.

\section{Conclusions}

For the first time, a full study of the influence of temperature and biowaste sterilization on the kinetics $\mathrm{CO}$ production is presented. The experiment showed an increase in CO production and $\mathrm{k}$ value with temperature. Depending on the conditions (biotic or abiotic) and the temperature, different $\mathrm{CO}$ production processes were observed. In both variants, the $\mathrm{CO}$ production increased. However, in the temperature range from $10 \sim 50{ }^{\circ} \mathrm{C}$, higher $\mathrm{CO}$ production was observed in biotic conditions, suggesting that the biological transformation is responsible for $\mathrm{CO}$ formation. Above $50^{\circ} \mathrm{C}$, the $\mathrm{CO}$ production was higher under abiotic conditions, suggesting that the thermochemical process was more efficient. Additionally, the constant rate $(\mathrm{k})$ value of $\mathrm{CO}$ production under biotic conditions was increasing up to a temperature of $60^{\circ} \mathrm{C}$, above which a slight decrease in $\mathrm{CO}$ production rate was observed at $70{ }^{\circ} \mathrm{C}$. The 1 st-order model described the $\mathrm{CO}$ production in $<50^{\circ} \mathrm{C}$ range; the 0 -order model was better for $>50^{\circ} \mathrm{C}$.

These observations indicate that the kinetic process of $\mathrm{CO}$ production is both abiotic and biotic. Observation of $\mathrm{CO}$ emissions under abiotic conditions indicates the thermochemical nature of $\mathrm{CO}$ production. Own previous studies have shown a significant impact of $\mathrm{O}_{2}$ consumption on $\mathrm{CO}$ production under both abiotic and biotic conditions. Higher $\mathrm{CO}$ emissions under abiotic conditions at $>50{ }^{\circ} \mathrm{C}$ indicated that microorganisms were metabolizing thermochemically produced $\mathrm{CO}$ in the biotic variant. However, in the psychrophilic and mesophilic temperature range $\left(10 \sim 40{ }^{\circ} \mathrm{C}\right)$, higher $\mathrm{CO}$ production under biotic conditions indicated the presence of $\mathrm{CO}$ producing microorganisms. The presented results are the basis for further studies on the possibility of controlling CO production during the biowaste aerobic biostabilization process.

Supplementary Materials: The following are available online at http://www.mdpi.com/1996-1073/13/20/5451/s1, Supplementary Materials CO kinetic.xlsx.

Author Contributions: Conceptualization, A.B., J.A.K.; methodology, A.B., S.S.-D.; validation, A.B., S.S.-D.; formal analysis, A.B., S.S.-D., and J.A.K.; investigation, S.S.-D., K.S.; resources, S.S.-D.; data curation, A.B., S.S.-D., and K.S.; writing - original draft preparation, S.S-D.; writing-review and editing, A.B., S.S.-D., K.S., J.B., and J.A.K.; visualization, S.S.-D., K.S.; supervision, A.B., J.B.; funding acquisition, S.S.-D. All authors have read and agreed to the published version of the manuscript. 
Funding: This research was funded by the Ph.D. research program 'InnowacyjnyDoktorat'(no. D220/0002/17) and financially supported by the Wrocław University of Environmental and Life Sciences. This research was partially supported by the Iowa Agriculture and Home Economics Experiment Station, Ames, Iowa. Project no. IOW05556 (Future Challenges in Animal Production Systems: Seeking Solutions through Focused Facilitation) sponsored by Hatch Act \& State of Iowa funds.

Acknowledgments: The presented article results were obtained as part of the activity of the leading research team-Waste and Biomass Valorization Group (WBVG), https://www.upwr.edu.pl/research/50121/waste_and_ biomass_valorization_group_wbvg.html.

Conflicts of Interest: The authors declare no conflict of interest.

\section{Appendix A}
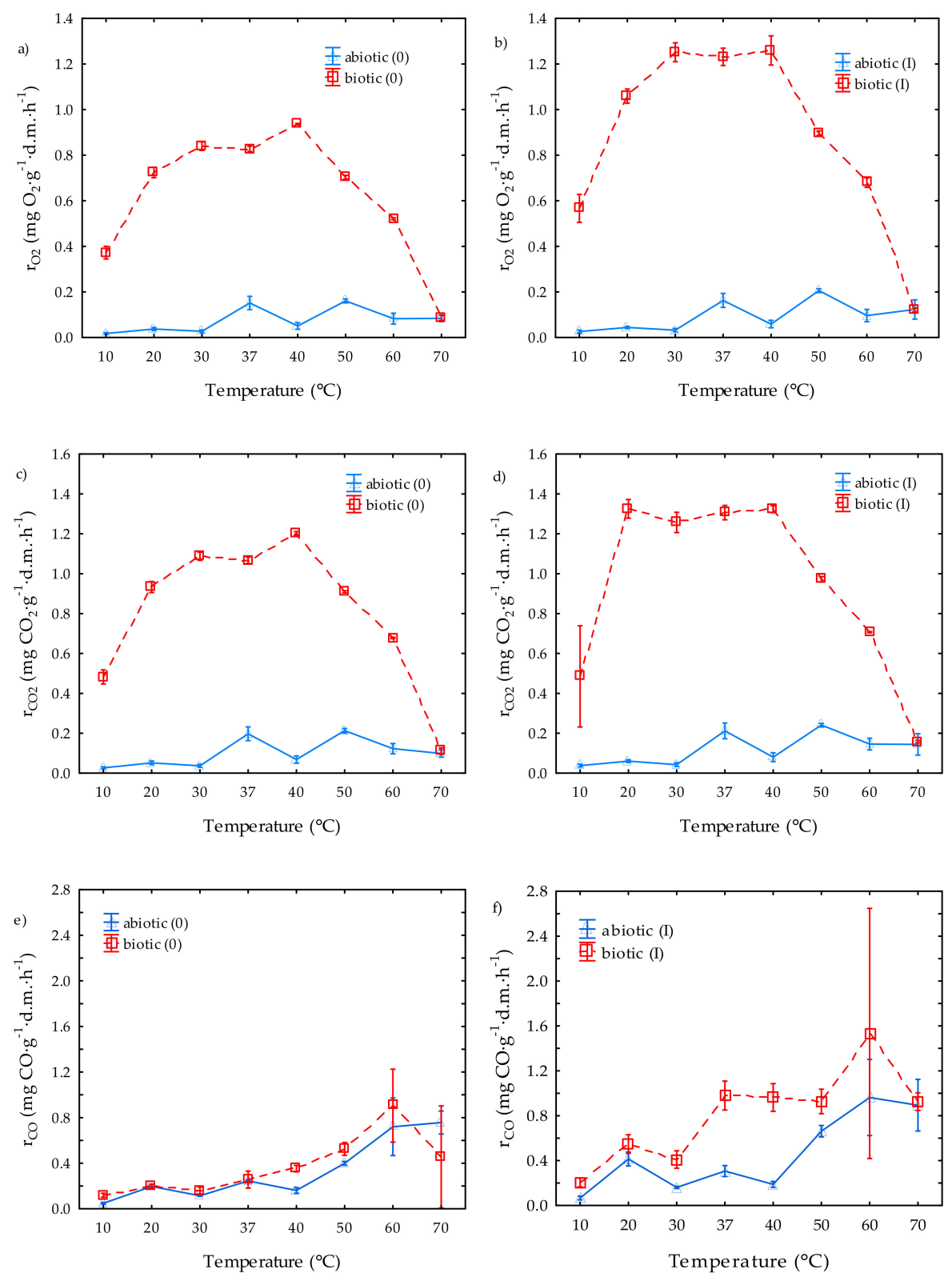

Figure A1. Average production and consumption rate $\left(\mathrm{r}_{\mathrm{O} 2}\right)\left(\right.$ a) $\mathrm{O}_{2}$ consumption 0-order kinetic, (b) $\mathrm{O}_{2}$ consumption I-order kinetic, (c) $\mathrm{CO}_{2}$ production 0-order kinetic, (d) $\mathrm{CO}_{2}$ production I-order kinetic, (e) CO production 0-order kinetic, (f) $\mathrm{CO}$ production 0-order kinetic. The error bars are showing +/- standard deviation around the mean. The kinetic values are shown in Tables S2.1-S2.3 (Supplementary Materials, sheets 4-6). 
Table A1. Kinetic model of $\mathrm{O}_{2}$ consumption and $\mathrm{CO}_{2}$ and $\mathrm{CO}$ used for process estimation (based on average results and $\mathrm{R}^{2}$ ). The kinetic values are shown in Tables S2.1-S2.3 (Supplementary Materials, sheets 4-6).

\begin{tabular}{|c|c|c|c|}
\hline Production or Consumption & $\begin{array}{c}\text { Temperature } \\
{ }^{\circ} \mathrm{C}\end{array}$ & Abiotic & Biotic \\
\hline \multirow{8}{*}{$\mathrm{O}_{2}$} & 10 & $\mathrm{O}_{2}=4.16 \cdot\left(1-e^{-0.0064 \cdot t}\right)$ & $\mathrm{O}_{2}=77.92 \cdot\left(1-e^{-0.0072 \cdot t}\right)$ \\
\hline & 20 & $O_{2}=19.46 \cdot\left(1-e^{-0.0032 \cdot t}\right)$ & $O_{2}=159.23 \cdot\left(1-e^{-0.0067 \cdot t}\right)$ \\
\hline & 30 & $O_{2}=15.93 \cdot\left(1-e^{-0.0028 \cdot t^{\prime}}\right)$ & $\mathrm{O}_{2}=174.37 \cdot\left(1-e^{-0.0072 \cdot t}\right)$ \\
\hline & 37 & $\mathrm{O}_{2}=0.1516 \cdot t$ & $\mathrm{O}_{2}=0.8277 \cdot t$ \\
\hline & 40 & $\mathrm{O}_{2}=0.0505 \cdot t$ & $\mathrm{O}_{2}=0.9362 \cdot t$ \\
\hline & 50 & $\mathrm{O}_{2}=0.1606 \cdot t$ & $\mathrm{O}_{2}=0.7034 \cdot t$ \\
\hline & 60 & $\mathrm{O}_{2}=0.0827 \cdot t$ & $\mathrm{O}_{2}=0.5207 \cdot t$ \\
\hline & 70 & $\mathrm{O}_{2}=30.61 \cdot\left(1-e^{-0.0053 \cdot t}\right)$ & $\mathrm{O}_{2}=25.29 \cdot\left(1-e^{-0.0060 \cdot t}\right)$ \\
\hline \multirow{8}{*}{$\mathrm{CO}_{2}$} & 10 & $\mathrm{CO}_{2}=6.39 \cdot\left(1-e^{-0.0060 \cdot t}\right)$ & $\mathrm{CO}_{2}=68.05 \cdot\left(1-e^{-0.0071 \cdot t}\right)$ \\
\hline & 20 & $\mathrm{CO}_{2}=0.0516 \cdot t$ & $\mathrm{CO}_{2}=228.41 \cdot\left(1-e^{-0.0058 \cdot t}\right)$ \\
\hline & 30 & $\mathrm{CO}_{2}=0.0369 \cdot t$ & $\mathrm{CO}_{2}=610.86 \cdot\left(1-e^{-0.0022 \cdot t^{\prime}}\right)$ \\
\hline & 37 & $\mathrm{CO}_{2}=0.1975 \cdot t$ & $\mathrm{CO}_{2}=421.37 \cdot\left(1-e^{-0.0032 \cdot t}\right)$ \\
\hline & 40 & $\mathrm{CO}_{2}=0.0681 \cdot t$ & $\mathrm{CO}_{2}=1.2022 \cdot t$ \\
\hline & 50 & $\mathrm{CO}_{2}=0.2410 \cdot t$ & $\mathrm{CO}_{2}=1049.7 \cdot\left(1-e^{-0.0010 \cdot t}\right)$ \\
\hline & 60 & $\mathrm{CO}_{2}=0.1232 \cdot t$ & $\mathrm{CO}_{2}=0.6782 \cdot t$ \\
\hline & 70 & $\mathrm{CO}_{2}=35.51 \cdot\left(1-e^{-0.0050 \cdot t}\right)$ & $\mathrm{CO}_{2}=42.58 \cdot\left(1-e^{-0.0064 \cdot t}\right)$ \\
\hline \multirow{8}{*}{$\mathrm{CO}$} & 10 & $C O=13.04 \cdot\left(1-e^{-0.0053 \cdot t}\right)$ & $C O=21.09 \cdot\left(1-e^{-0.0097 \cdot t}\right)$ \\
\hline & 20 & $C O=30.08 \cdot\left(1-e^{-0.0138 \cdot t}\right)$ & $C O=25.62 \cdot\left(1-e^{-0.0214 \cdot t^{\prime}}\right)$ \\
\hline & 30 & $C O=28.36 \cdot\left(1-e^{-0.0057 \cdot t^{\prime}}\right)$ & $C O=22.14 \cdot\left(1-e^{-0.194 \cdot t}\right)^{\prime}$ \\
\hline & 37 & $C O=95.57 \cdot\left(1-e^{-0.0038 \cdot t^{\prime}}\right)$ & $C O=32.32 \cdot\left(1-e^{-0.0312 \cdot t}\right)$ \\
\hline & 40 & $C O=0.1608 \cdot t$ & $C O=48.28 \cdot\left(1-e^{-0.0204 \cdot t^{\prime}}\right)$ \\
\hline & 50 & $C O=77.48 \cdot\left(1-e^{-0.0088 \cdot t}\right)$ & $C O=95.64 \cdot\left(1-e^{-0.0098 \cdot t^{\prime}}\right)$ \\
\hline & 60 & $C O=0.7194 \cdot t$ & $C O=0.9047 \cdot t$ \\
\hline & 70 & $C O=0.7563 \cdot t$ & $C O=0.4543 \cdot t$ \\
\hline
\end{tabular}

\section{References}

1. Techtmann, S.M.; Colman, A.S.; Robb, F.T. That which does not kill us only makes us stronger: The role of carbon monoxide in thermophilic microbial consortia. Environ. Microbiol. 2009, 11, 1027-1037. [CrossRef]

2. Ahmad Farid, M.A.; Hassan, M.A.; Roslan, A.M.; Samsudin, M.H.; Mohamad, Z.J.J.; Othman, M.R.; Shirai, Y. Carbon monoxide reduction in the flue gas during biochar production from oil palm empty fruit bunch. J. Clean. Prod. 2020, 258, 120580. [CrossRef]

3. Haarstad, K.; Bergersen, O.; Sorheim, R. Occurrence of carbon monoxide during organic waste degradation. J. Air Waste Manag. Assoc. 2006, 56, 575-580. [CrossRef] [PubMed]

4. Stegenta-Dabrowska, S.; Drabczyński, G.; Sobieraj, K.; Koziel, J.A.; Białowiec, A. The biotic and abiotic carbon monoxide formation during aerobic co-digestion of dairy cattle manure with green waste and sawdust. Front. Bioeng. Biotechnol. 2019, 7, 283. [CrossRef] [PubMed]

5. Hellebrand, H.J.; Kalk, W.D. Emission of carbon monoxide during composting of dung and green waste. Nutr. Cycl. Agroecosyst. 2001, 60, 79-82. [CrossRef]

6. Stegenta, S.; Dębowski, M.; Bukowski, P.; Randerson, P.F.; Białowiec, A. The influence of perforation of foil reactors on greenhouse gas emission rates during aerobic biostabilization of the undersize fraction of municipal wastes. J. Environ. Manag. 2018, 207, 355. [CrossRef]

7. Hellebrand, H.J. Emission of nitrous oxide and other trace gases during composting of grass and green waste. J. Agric. Eng. Res. 1998, 69, 365-375. [CrossRef]

8. Boldrin, A.; Andersen, J.K.; Moller, J.; Christensen, T.H.; Favoino, E. Composting and compost utilization: Accounting of greenhouse gases and global warming contributions. Waste Manag. Res. 2009, 27, 800-812. [CrossRef] 
9. Cayuela, M.L.; Sanchez-Monedero, M.A.; Roig, A.; Sinicco, T.; Mondini, C.; Luz Cayuela, M.; Angel Sanchez-Monedero, M.; Roig, A.; Sinicco, T.; Mondini, C. Biochemical changes and GHG emissions during composting of lignocellulosic residues with different $\mathrm{N}$-rich by-products. Chemosphere 2012, 88, 196-203. [CrossRef]

10. Colon, J.; Cadena, E.; Pognani, M.; Barrena, R.; Sanchez, A.; Font, X.; Artola, A. Determination of the energy and environmental burdens associated with the biological treatment of source-separated Municipal Solid Wastes. Energy Environ. Sci. 2012, 5, 5731-5741. [CrossRef]

11. Ermolaev, E.; Pell, M.; Smårs, S.; Sundberg, C.; Jönsson, H.; Smars, S.; Sundberg, C.; Jonsson, H. Greenhouse gas emission from covered windrow composting with controlled ventilation. Waste Manag. Res. 2012, 30, 155-160. [CrossRef] [PubMed]

12. Daou, A.; Mallat, C.; Chammas, G.; Cerantola, N.; Kayed, S.; Saliba, N.A. The Ecocanvas as a business model canvas for a circular economy. J. Clean. Prod. 2020, 258, 120938. [CrossRef]

13. Sironi, S.; Botta, D. Biofilter efficiency in odor abatement at composting plants. Compost Sci. Util. 2001, 9, 149-155. [CrossRef]

14. Stegenta, S.; Sobieraj, K.; Pilarski, G.; Koziel, J.; Białowiec, A. The spatial and temporal distribution of process gases within the biowaste compost. Data 2019, 4, 37. [CrossRef]

15. Szanto, G.L.; Hamelers, H.M.; Rulkens, W.H.; Veeken, A.H.M. $\mathrm{NH}_{3}, \mathrm{~N}_{2} \mathrm{O}$ and $\mathrm{CH}_{4}$ emissions during passively aerated composting of straw-rich pig manure. Bioresour. Technol. 2007, 98, 2659-2670. [CrossRef] [PubMed]

16. Clemens, J.; Cuhls, C. Greenhouse gas emissions from mechanical and biological waste treatment of municipal waste. Environ. Technol. 2003, 24, 745-754. [CrossRef] [PubMed]

17. Amlinger, F.; Peyr, S.; Cuhls, C. Green house gas emissions from composting and mechanical biological treatment. Waste Manag. Res. 2008, 26, 47-60. [CrossRef]

18. Boldrin, A.; Andersen, J.K.; Christensen, T.H. Environmental assessment of garden waste management in the Municipality of Aarhus, Denmark. Waste Manag. 2011, 31, 1560-1569. [CrossRef]

19. Hellebrand, H.; Schade, G.W.; Idler, C.; Kern, J. Carbon monoxide from composting due to thermal oxidation of biomass: An additional pathway for co in agricultural and forest ecosystems. In Proceedings of the Workshop on Agricultural Air Quality: State of the Science, Potomac, MA, USA, 4-8 June 2006; pp. 693-705.

20. Conrad, R.; Seiler, W. Role of microorganisms in the consumption and production of atmospheric carbon monoxide by soil. Appl. Environ. Microbiol. 1980, 40, 437-445. [CrossRef]

21. Zepp, R.G.; Miller, W.L.; Tarr, M.A.; Burke, R.A.; Stocks, B.J. Soil-atmosphere fluxes of carbon monoxide during early stages of postfire succession in upland Canadian boreal forests. J. Geophys. Res. Atmos. 1997, 102, 29301-29311. [CrossRef]

22. Fraser, W.T.; Blei, E.; Fry, S.C.; Newman, M.F.; Reay, D.S.; Smith, K.A.; McLeod, A.R. Emission of methane, carbon monoxide, carbon dioxide and short-chain hydrocarbons from vegetation foliage under ultraviolet irradiation. Plant Cell Environ. 2015, 38, 980-989. [CrossRef] [PubMed]

23. van Asperen, H.; Warneke, T.; Sabbatini, S.; Nicolini, G.; Papale, D.; Notholt, J. The role of photo- and thermal degradation for $\mathrm{CO}_{2}$ and $\mathrm{CO}$ fluxes in an arid ecosystem. Biogeosciences 2015, 12, 4161-4174. [CrossRef]

24. Rich, J.J.; King, G.M. Carbon monoxide consumption and production by wetland peats. FEMS Microbiol. Ecol. 1999, 28, 215-224. [CrossRef]

25. Goldstein, J.; Goldstein, N. Controlling odors at composting facilities. Biocycle 2005, 46, 22.

26. Bünger, J.; Schappler-Scheele, B.; Hilgers, R.; Hallier, E. A 5-year follow-up study on respiratory disorders and lung function in workers exposed to organic dust from composting plants. Int. Arch. Occup. Environ. Health 2007, 80, 306-312. [CrossRef] [PubMed]

27. Herr, C.E.W.; Nieden, A.; Seitz, H.; Harpel, S.; Stinner, D.; Stilianakis, N.; Eikmann, T. Bioaerosols in outdoor air-Statement of environmental medical assessment criteria on the basis of an epidemiological cross sectional study. Gefahrst. Reinhalt. Luft 2004, 64, 143-152.

28. Müller, T.; Jörres, R.; Scharrer, E.; Hessel, H.; Nowak, D.; Radon, K. Acute blood neutrophilia induced by short-term compost dust exposure in previously unexposed healthy individuals. Int. Arch. Occup. Environ. Health 2006, 79, 477-482. [CrossRef] [PubMed]

29. Müller, T.; Thissen, R.; Braun, S.; Dott, W.; Fischer, G. (M)VOC and composting facilities-Part 2: (M)VOC dispersal in the environment. Environ. Sci. Pollut. Res. Int. 2004, 11, 152. [CrossRef]

30. Koskela, R.S.; Mutanen, P.; Sorsa, J.; Klockars, M. Factors predictive of ischemic heart disease mortality in foundry workers exposed to carbon monoxide. Am. J. Epidemiol. 2000, 152, 628-632. [CrossRef] 
31. Pikoń, K.; Rejman, R. Carbon cycle in municipal solid waste managements. Arch. Gospod. Odpad. 2009, 11, 27-46.

32. Eaton, A.D.; Clesceri, L.S.; Greenberg, A.E.; Franson, M.A.H. Standard Methods for the Examination of Water and Wastewater; American Public Health Association: Washington, DC, USA, 1998.

33. Yu, Q.; Li, H. Moderate separation of household kitchen waste towards global optimization of municipal solid waste management. J. Clean. Prod. 2020, 277, 123330. [CrossRef]

34. Binner, E.; Bohm, K.; Lechner, P. Large scale study on measurement of respiration activity (AT(4)) by Sapromat and OxiTop. Waste Manag. 2012, 32, 1752-1759. [CrossRef] [PubMed]

35. Kilian, E.; Macedowska-Capiga, A. Parametr AT4 jako wskaźnik stopnia stabilizacji odpadów po mechaniczno-biologicznym przetworzeniu (AT4 parameter as an indicator of the degree of stabilization of waste after mechanical and biological treatment). Pr. Inst. Ceram. Mater. Bud. 2011, 4, 88-94.

36. Stegenta, S.; Kałdun, B.; Białowiec, A. Model selection and estimation of kinetic parameters of oxygen consumption during biostabilization of under-size fraction of municipal solid waste. Rocz. Ochr. Sr. 2016, 18, 800-814.

37. Burnham, K.P.; Anderson, D.R.; Burnham, K.P. Model Selection and Multimodel Inference: A Practical Information-Theoretic Approach; Springer: Berlin/Heidelberg, Germany, 2002.

38. Jiang, T.; Schuchardt, F.; Li, G.; Guo, R.; Zhao, Y. Effect of C/N ratio, aeration rate and moisture content on ammonia and greenhouse gas emission during the composting. J. Environ. Sci. 2011, 23, 1754-1760. [CrossRef]

39. Fukumoto, Y.; Suzuki, K.; Kuroda, K.; Waki, M.; Yasuda, T. Effects of struvite formation and nitratation promotion on nitrogenous emissions such as $\mathrm{NH}_{3}, \mathrm{~N}_{2} \mathrm{O}$ and $\mathrm{NO}$ during swine manure composting. Bioresour. Technol. 2011, 102, 1468-1474. [CrossRef]

40. Albrecht, R.; Joffre, R.; Gros, R.; Le Petit, J.; Terrom, G.; Perissol, C. Efficiency of near-infrared reflectance spectroscopy to assess and predict the stage of transformation of organic matter in the composting process. Bioresour. Technol. 2008, 99, 448-455. [CrossRef]

41. Dach, J. Kompostowanie trawy i liści (Grass and leaves composting). Przegląd Komunal. 2008, 10, 36-39.

42. Kumar, M.; Ou, Y.; Lin, J. Co-composting of green waste and food waste at low C/N ratio. Waste Manag. 2010, 30, 602-609. [CrossRef]

43. Adhikari, B.K.; Trémier, A.; Barrington, S.; Martinez, J. Biodegradability of municipal organic waste: A respirometric test. Waste Biomass. Valor. 2013, 4, 331-340. [CrossRef]

44. Sun, W.; Huang, G.H.; Zeng, G.; Qin, X.; Sun, X. A stepwise-cluster microbial biomass inference model in food waste composting. Waste Manag. 2009, 29, 2956-2968. [CrossRef] [PubMed]

45. Mason, I.G. Mathematical modelling of the composting process: A review. Waste Manag. 2006, $26,3-21$. [CrossRef] [PubMed]

46. Sobieraj, K.; Stegenta, S.; Białowiec, A. The use of respiration activity method for predicting easily biodegradable fractions in organic waste. Przem. Chem. 2017, 96. [CrossRef]

47. Wetzel, S.; Volpe, S.; Damianopoulos, J.; Krigstin, S. Can biomass quality be preserved through tarping comminuted roadside biomass piles? Forests 2017, 8, 305. [CrossRef]

48. de Guardia, A.; Petiot, C.; Rogeau, D.; Druilhe, C. Influence of aeration rate on nitrogen dynamics during composting. Waste Manag. 2008, 28, 575-587. [CrossRef]

49. Mason, I.G.; Milke, M.W. Physical modelling of the composting environment: A review. Part 1: Reactor systems. Waste Manag. 2005, 25, 481-500. [CrossRef]

50. Evangelou, A.; Calabrò, P.S.; Greco, R.; Sánchez, A.; Komilis, D. Biodegradation activity of eight organic substrates: A correlation study of different test methods. Waste Biomass. Valor. 2016, 7, 1067-1080. [CrossRef]

51. Barrena, R.; d’Imporzano, G.; Ponsa, S.; Gea, T.; Artola, A.; Vazquez, F.; Sanchez, A.; Adani, F. In search of a reliable technique for the determination of the biological stability of the organic matter in the mechanical-biological treated waste. J. Hazard. Mater. 2009, 162, 1065-1072. [CrossRef]

52. Sadecka, Z.; Suchowska-Kisielewicz, M. The possibility of using organic substrates in the fermentation process. Rocz. Ochr. Sr. 2016, 18, 400-413.

53. Manu, M.K.; Kumar, R.; Garg, A. drum composting of food waste: A kinetic study. Procedia Environ. Sci. 2016, 35, 456-463. [CrossRef] 
54. Fernandez, F.J.; Sanchez-Arias, V.; Villasenor, J.; Rodriguez, L. Evaluation of carbon degradation during co-composting of exhausted grape marc with different biowastes. Chemosphere 2008, 73, 670-677. [CrossRef] [PubMed]

55. Kuwahara, F.; Sano, Y.; Nakayama, A.; Nakasaki, K.; Fukazawa, T. Numerical modeling of a composting process with aeration. J. Porous Media 2009, 12, 927-938. [CrossRef]

56. Ermolaev, E.; Sundberg, C.; Pell, M.; Smårs, S.; Jönsson, H. Effects of moisture on emissions of methane, nitrous oxide and carbon dioxide from food and garden waste composting. J. Clean Prod. 2019, 240, 118165. [CrossRef]

57. Beck-Friis, B.; Smårs, S.; Jönsson, H.; Eklind, Y.; Kirchmann, H. Composting of source-separated household organics at different oxygen levels: Gaining an understanding of the emission dynamics. Compost Sci. Util. 2003, 11, 41-50. [CrossRef]

58. Nasini, L.; De Luca, G.; Ricci, A.; Ortolani, F.; Caselli, A.; Massaccesi, L.; Regni, L.; Gigliotti, G.; Proietti, P. Gas emissions during olive mill waste composting under static pile conditions. Int. Biodeterior. Biodegrad. 2016, 107, 70-76. [CrossRef]

59. Hao, J.; Wang, H. Volatile fatty acids productions by mesophilic and thermophilic sludge fermentation: Biological responses to fermentation temperature. Bioresour. Technol. 2015, 175, 367-373. [CrossRef] [PubMed]

60. Sommer, S.G.; Moller, H.B. Emission of greenhouse gases during composting of deep litter from pig production-effect of straw content. J. Agric. Sci. 2000, 134, 327-335. [CrossRef]

61. Kulcu, R.; Yaldiz, O. Effects of air flow directions on composting process temperature profile. Waste Manag. 2008, 28, 1766-1772. [CrossRef]

62. Sun, X.; Ma, S.; Han, L.; Li, R.; Schlick, U.; Chen, P.; Huang, G. The effect of a semi-permeable membrane-covered composting system on greenhouse gas and ammonia emissions in the Tibetan Plateau. J. Clean Prod. 2018, 204, 778-787. [CrossRef]

63. Puyuelo, B.; Gea, T.; Sánchez, A. A new control strategy for the composting process based on the oxygen uptake rate. Chem. Eng. J. 2010, 165, 161-169. [CrossRef]

64. Stegenta, S.; Sobieraj, K.; Pilarski, G.; Koziel, J.A.; Białowiec, A. Analysis of the spatial and temporal distribution of process gases within municipal biowaste compost. Sustainability 2019, 11, 2340. [CrossRef]

65. Awasthi, S.K.; Sarsaiya, S.; Awasthi, M.K.; Liu, T.; Zhao, J.; Kumar, S.; Zhang, Z. Changes in global trends in food waste composting: Research challenges and opportunities. Bioresour. Technol. 2020, 299, 122555. [CrossRef]

66. Li, Y.; Li, W.; Wu, C.; Wang, K. New insights into the interactions between carbon dioxide and ammonia emissions during sewage sludge composting. Bioresour. Technol. 2013, 136, 385-393. [CrossRef]

67. Vasiliadou, I.A.; Muktadirul Bari Chowdhury, A.K.M.; Akratos, C.S.; Tekerlekopoulou, A.G.; Pavlou, S.; Vayenas, D.V. Mathematical modeling of olive mill waste composting process. Waste Manag. 2015, 43, 61-71. [CrossRef] [PubMed]

68. Tatano, F.; Pagliaro, G.; Di Giovanni, P.; Floriani, E.; Mangani, F. Biowaste home composting: Experimental process monitoring and quality control. Waste Manag. 2015, 38, 72-85. [CrossRef] [PubMed]

69. Petric, I.; Helić, A.; Avdić, E.A. Evolution of process parameters and determination of kinetics for co-composting of organic fraction of municipal solid waste with poultry manure. Bioresour. Technol. 2012, 117, 107-116. [CrossRef]

70. Ge, J.; Huang, G.; Huang, J.; Zeng, J.; Han, L. Mechanism and kinetics of organic matter degradation based on particle structure variation during pig manure aerobic composting. J. Hazard Mater. 2015, 292, 19-26. [CrossRef]

71. Siles-Castellano, A.B.; López, M.J.; Jurado, M.M.; Suárez-Estrella, F.; López-González, J.A.; Estrella-González, M.J.; Moreno, J. Industrial composting of low carbon/nitrogen ratio mixtures of agri-food waste and impact on compost quality. Bioresour. Technol. 2020, 316, 123946. [CrossRef]

72. Paillat, J.-M.; Robin, P.; Hassouna, M.; Leterme, P. Predicting ammonia and carbon dioxide emissions from carbon and nitrogen biodegradability during animal waste composting. Atmos. Environ. 2005, 39, 6833-6842. [CrossRef]

73. Wu, C.; Li, W.; Wang, K.; Li, Y. Usage of pumice as bulking agent in sewage sludge composting. Bioresour. Technol. 2015, 190, 516-521. [CrossRef] 
74. Tosun, I.; Gonullu, M.T.; Arslankaya, E.; Gunay, A. Co-composting kinetics of rose processing waste with OFMSW. Bioresour. Technol. 2008, 99, 6143-6149. [CrossRef] [PubMed]

75. Shao, L.; Wang, T.; Li, T.; Lü, F.; He, P. Comparison of sludge digestion under aerobic and anaerobic conditions with a focus on the degradation of proteins at mesophilic temperature. Bioresour. Technol. 2013, 140, 131-137. [CrossRef]

76. Hosseini, S.M.; Aziz, H.A. Evaluation of thermochemical pretreatment and continuous thermophilic condition in rice straw composting process enhancement. Bioresour. Technol. 2013, 133, 240-247. [CrossRef] [PubMed]

77. Ma, C.; Lo, P.K.; Xu, J.; Li, M.; Jiang, Z.; Li, G.; Zhu, Q.; Li, X.; Leong, S.Y.; Li, Q. Molecular mechanisms underlying lignocellulose degradation and antibiotic resistance genes removal revealed via metagenomics analysis duringdifferent agricultural wastes composting. Bioresour. Technol. 2020, 314, 123731. [CrossRef] [PubMed]

78. Tremier, A.; De Guardia, A.; Massiani, C.; Martel, J.L. Influence of the airflow rate on heat and mass transfers during sewage sludge and bulking agent composting. Environ. Technol. 2005, 26, 1137-1149. [CrossRef]

79. Tang, J.C.; Shibata, A.; Zhou, Q.; Katayama, A. Effect of temperature on reaction rate and microbial community in composting of cattle manure with rice straw. J. Biosci. Bioeng. 2007, 104, 321-328. [CrossRef] [PubMed]

80. Yu, S.H.; Clark, O.G.; Leonard, J.J. Influence of free air space on microbial kinetics in passively aerated compost. Bioresour. Technol. 2009, 100, 782-790. [CrossRef]

81. Chen, M.; Huang, Y.; Liu, H.; Xie, S.; Abbas, F. Impact of different nitrogen source on the compost quality and greenhouse gas emissions during composting of garden waste. Process Saf. Environ. Prot. 2019, 124, 326-335. [CrossRef]

82. Burtraw, D.; Toman, M. The Benefits of Reduced Air Pollutants in the U.S. from Greenhouse Gas Mitigation Policies; Discussion Paper 98-01-REV; University of Minnesota: St. Paul, MN, USA, 1997; p. 10496. [CrossRef]

Publisher's Note: MDPI stays neutral with regard to jurisdictional claims in published maps and institutional affiliations. 